\title{
Lithostratigraphic framework of the Upper Proterozoic Eleonore Bay Supergroup of East and North-East Greenland
}

G E U S

Report file no.

22319

Martin Sønderholm and Henrik Tirsgaard

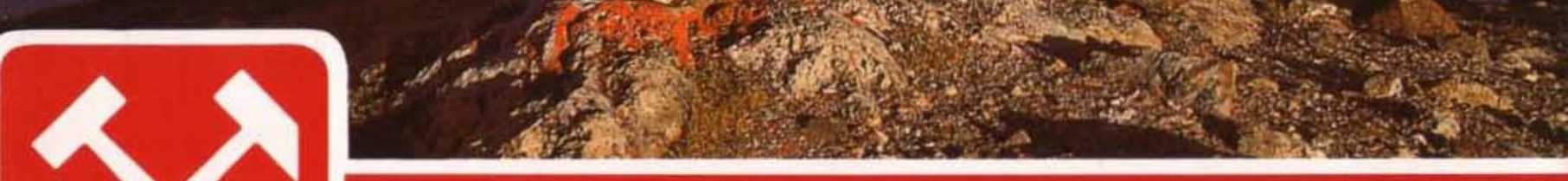

GRØNLANDS GEOLOGISKE UNDERSØGELSE

GGU Bulletin 167

1993 
GRøNLANDS GEOLOGISKE UNDERS $\emptyset$ GELSE

Bulletin 167

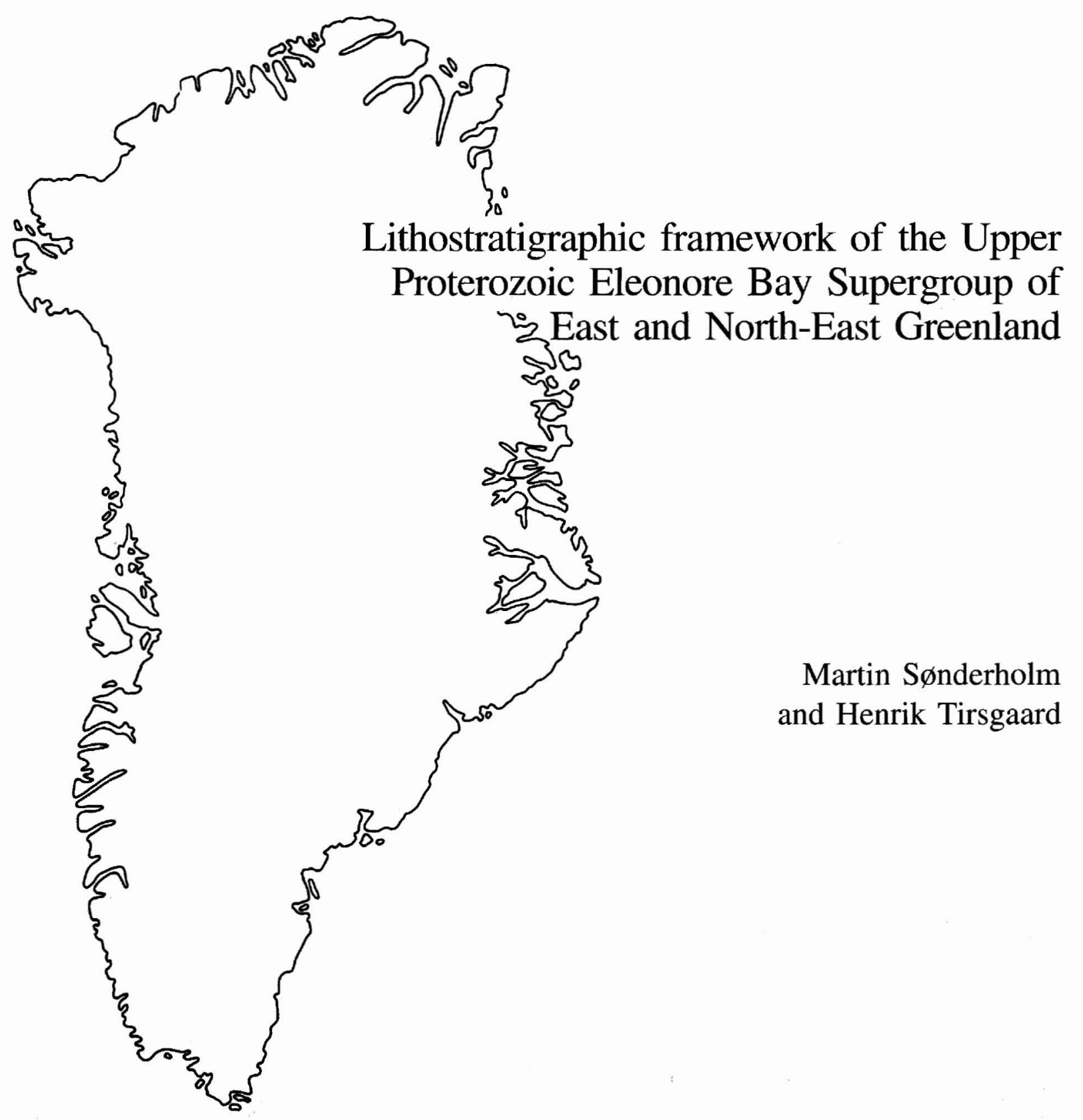


Sønderholm, M. \& Tirsgaard, H. 1993: Lithostratigraphic framework of the Upper Proterozoic Eleonore Bay Supergroup of East and North-East Greenland. Bull. Grønlands geol. Unders. 167, $38 \mathrm{pp}$.

In the region between Canning Land $\left(71^{\circ} 30^{\prime} \mathrm{N}\right)$ and Bessel Fjord $\left(76^{\circ} \mathrm{N}\right)$ the Eleonore Bay Supergroup is up to $16 \mathrm{~km}$ thick and comprises both metasediments and sediments. It is divided into five new groups. In the eastern outcrops four groups are found; these are from base to top: the Nathorst Land Group (up to $c .11000 \mathrm{~m}$ thick), the Lyell Land Group (2000-2800 m thick), the Ymer Ø Group (900-1300 m thick) and the Andrée Land Group (900-1500 m thick). The lower two of these groups consist of alternating sandstones and mudstones (and their metamorphic equivalents). Information on the depositional environment of the Nathorst Land Group is scarce, but both fluvial and marine settings have been tentatively proposed. The Lyell Land Group mainly represents marine shelf environments. The Ymer $\emptyset$ and Andrée Land Groups are dominated by carbonates deposited in a platform, slope and basinal environment.
Furthest west, in the nunatak region, a succession of sandstones and mudstones more than $6300 \mathrm{~m}$ thick is included in the Petermann Bjerg Group. The stratigraphic relationship between the Petermann Bjerg Group and the rest of the Eleonore Bay Supergroup is uncertain but possibly correlates with parts of the Nathorst Land and Lyell Land Groups.

The Eleonore Bay Supergroup is finally compared with other Upper Proterozoic successions in the North Atlantic region.

\section{Authors' addresses:}

M. S., Geological Survey of Greenland, Øster Voldgade 10, DK-1350 Copenhagen K, Denmark.

H. T., Geological Survey of Greenland, Øster Voldgade 10, DK-1350 Copenhagen K, Denmark. Present address: Mærsk Olie og Gas AS, Esplanaden 50, DK-1263 Copenhagen K, Denmark.

\section{Grønlands Geologiske Undersøgelse Ujarassiortut Kalaallit Nunaanni Misissuisoqarfiat Geological Survey of Greenland}

The Geological Survey of Greenland (GGU) is a research institute affiliated to the Mineral Resources Administration for Greenland (MRA) within the Danish Ministry of Energy. As with all other activities involving the non-living resources in Greenland, GGU's investigations are carried out within the framework of the policies decided jointly by the Greenland Home Rule Authority and the Danish State. 


\section{Contents}

Dansk sammendrag - Imaqarnersiuineq .......... 4

Introduction $\ldots \ldots \ldots \ldots \ldots \ldots \ldots \ldots \ldots \ldots \ldots$

Previous work $\ldots \ldots \ldots \ldots \ldots \ldots \ldots \ldots \ldots \ldots \ldots$

Terminology. ..................... 10

Lithostratigraphy .................. 11

Eleonore Bay Supergroup. .............. 11

Nathorst Land Group ................. 13

Petermann Bjerg Group ............... 18
Lyell Land Group ..................... 21

Ymer $\varnothing$ Group . . . . . . . . . . . . . . . . . 24

Andrée Land Group ................. 28

Correlation with other areas in the

North Atlantic region $\ldots \ldots \ldots \ldots \ldots \ldots \ldots \ldots \ldots$

Acknowledgements ...................... 35

References......................... 35

\section{Cover picture}

Midnight view of Eleonore Bay Supergroup on western side of Ymer $\emptyset$. To the left (north) the dark grey top of the Lyell Land Group is exposed, overlain by the brigth coloured Ymer $\emptyset$ Group in the central part of the picture. To the left (south) the dark grey and white carbonates of the Andrée Land Group are seen, and furthest to the south the Tillite Group overlying the Eleonore Bay Supergroup is exposed. Highest part of cliffs is $1300 \mathrm{~m}$. 


\section{Dansk sammendrag}

Denne afhandling opretter formelt den $\emptyset$ vre proterozoiske Eleonore Bay Supergruppe i $\emptyset_{\text {st- }}$ og Nordøstgrønland i området mellem Canning Land $\left(71^{\circ} 30^{\prime} \mathrm{N}\right)$ og Bessel Fjord $\left(76^{\circ} \mathrm{N}\right)$. Endvidere defineres fem nye grupper, hvoraf de fire findes i den østlige fjordzone. Disse er fra basis til top: Nathorst Land Gruppen (c. $11000 \mathrm{~m}$ ), Lyell Land Gruppen (2000-2800 m), Ymer Ø Gruppen (900$1300 \mathrm{~m}$ ) og Andrée Land Gruppen $(900-1500 \mathrm{~m})$. De to nederste grupper består hovedsageligt af skiftende enheder af sandsten og muddersten aflejret i fluviatile (?) og marine miljøer. De to $\varnothing$ verste grupper består hovedsage- ligt af karbonater aflejret i platform, slope og bassin miljøer.

Længst mod vest i nunatakområdet findes endvidere en mere end $6300 \mathrm{~m}$ tyk sekvens bestående af vekslende sandsten og muddersten, som henregnes til Petermann Bjerg Gruppen. Korrelationen af denne med den øvrige Eleonore Bay Supergruppe er noget usikker, men kan sandsynligvis foretages med dele af Nathorst Land og Lyell Land Grupperne.

Afslutningsvis sammenlignes Eleonore Bay Supergruppen med andre $\emptyset$ vre proterozoiske sekvenser i det nordatlantiske område.

\section{Imaqarnersiuineq}

Allaserisami uvani Tunumi Tunullu avannaani Canning Landip $\left(71^{\circ} 30^{\prime} \mathrm{N}\right)$ Bessel Fjord-illu $\left(76^{\circ} \mathrm{N}\right)$ akornanni kinnganerit ujaranngorsimasut Eleonore Bay Supergruppe-mik taaguuserneqarsimasut pilersinneqarput. Kiisalu immikkoortut nutaat tallimat pilersinneqarput, taakkunanilu sisamat kangerluup kangiatungaaniipput. Taakkulu naqqaniit qaavanut tassaapput: Nathorst Land Gruppen (c. $11000 \mathrm{~m}$ ), Lyell Land Gruppen (20002800), Ymer Ø Gruppen (900-1300 m) kiisalu Andrée Land Gruppen (900-1500 m). Qalliit immikkoortut marluk tassaanerupput sillisissat marraallu ujaranngorsimasut imminnut akuleriissitaartut kuunni (?) imaanilu kiviorarsimasut. Immikkoortut marluk qalliit tassaanerupput ujaqqaq qequmik akullit qattunerni, sivinganerni imartunerunernilu pinngorsimasut.

Kippasinnerpaami nunataqarfimmi aamma sillisissanik marrarnillu ujaranngorsimasunik ujaraqarpoq $6300 \mathrm{~km}$-it sinnerlugit issussuseqartunik, taakkulu Petermann Bjerg Gruppemut ilatinneqarlutik. Eleonore Bay Supergrupp-ip sinneranut atassuteqarnersoq nalorngisigineqarpoq, Nathorst Land-ip Lyell Land Gruppinullu qularnanngitsumik ilaatigut atassuserneqarsinnaalluni.

Naggasiutaasumik Eleonore Bay Supergruppe atlantikup avannaanut kinnganernut ujaranngorsimasunut allanut proterozoikum-ip nalaani pinngorsimasunut naleqqiunneqarsinnaavoq. 


\section{Introduction}

Rocks of the Upper Proterozoic Eleonore Bay Supergroup (previously the Eleonore Bay Group) form a fundamental element in the East Greenland Caledonides (Fig. 1). They were first described by Toula (1874) and Lenz (1874), both members of the Second German North Pole Expedition in 1869-70 under the leadership of Karl Koldewey, and this succession has since attracted considerable attention. Previous geological investigations of this thick pile of metasediments and sediments, which reaches a thickness of $16 \mathrm{~km}$, have mainly been focused on their distribution and extent, and until recently relatively little was known concerning their more detailed sedimentological setting.

Haller (1971) regarded the pre-Caledonian sediments (Proterozoic-Ordovician) as deposited in a geosynclinal basin. The sedimentary prism includes four dominant cycles of sedimentation, of which the two lower cycles make up the Eleonore Bay Supergroup succession. The upper three cycles were considered as miogeosynclinal sediments, while the lowest cycle was thought to show some eugeosynclinal aspects due to the supposed association of metasediments and metavolcanic rocks. However, later work has shown that some of the assumed greenschists thought to be volcanic rocks are mylonitic developments, and other basic rocks included in the lowest cycle are of varied age and origin (Henriksen \& Higgins, 1976). Only one reliable occurrence of associated sediments and ophiolitic greenstones exists in the region (known as the 'Eleonore $\$ \emptyset$ Series'), but the stratigraphic relationship between this succession and the Ele- onore Bay Supergroup is at present unknown (Henriksen \& Higgins, 1976).

In a contribution to the sedimentology of the Eleonore Bay Supergroup, Caby \& Bertrand-Sarfati (1988) assumed that the sediments were deposited on a passive continental margin bordering the Iapetus Ocean. Based on brief sedimentological investigations in 1971 and 1975 in the southern outcrop areas, they suggested that the lower quartzitic part of the succession was deposited in continental and shallow marine environments, while the upper carbonate dominated part formed within a prograding sedimentary system on a carbonate shelf. However, the results provided by these authors are not sufficiently detailed to allow a critical and up-to-date evaluation of the sedimentological interpretations.

In order to gain more comprehensive sedimentological knowledge of parts of the Eleonore Bay Supergroup succession, the Geological Survey of Greenland initiated a project on this topic in 1988, supported by a grant from the Danish Natural Science Research Council (Sønderholm et al., 1989; Sønderholm \& Tirsgaard, 1990). At the same time a photogrammetric research project partly supported by the Carlsberg Foundation resulted in the compilation of a set of detailed geological maps of the Eleonore Bay Supergroup and the Devonian basin in the region between $72^{\circ} \mathrm{N}$ and $74^{\circ} 30^{\prime} \mathrm{N}$ (Bengaard, 1989, 1992a, b). This recent work prompted the need for a revision of the lithostratigraphy of the Eleonore Bay Supergroup succession.

\section{Previous work}

The first descriptions of rocks of the Eleonore Bay Supergroup were given by Toula (1874) and Lenz (1874) who compared strata occurring along the north coast of Kejser Franz Joseph Fjord and along the north coast of Eleonore Bugt (Fig. 2) with the Hekla Hook formation on Svalbard (Nordenskiöld, 1863) and loosely referred them to the Palaeozoic. The geological sketch map of the area around Kejser Franz Joseph Fjord made by this expedition thus simply refers these beds to the Hekla Hook formation (Hochstetter, 1874).

During his expedition to North-East Greenland in 1899, Nathorst (1901) also noted their close resemblance to rocks on Beeren Eiland (Bjørnøya; Svalbard). He realised, however, that the rocks assigned to the Hekla Hook formation by the German expedition could be divided into two formations: one showing strong folding which he referred to as 'Silurian' and one as of 'Devonian' age (Fig. 3).

The first systematic work on the geology of East Greenland was undertaken by 'Carlsbergfondets Expedition til Østgrønland' in 1898-1900 led by G. C. Amdrup. As a result of observations during this expedition, Nordenskjöld (1907) compiled the first comprehensive geological map of the area between $69^{\circ} \mathrm{N}$ and $75^{\circ} \mathrm{N}$, and on 


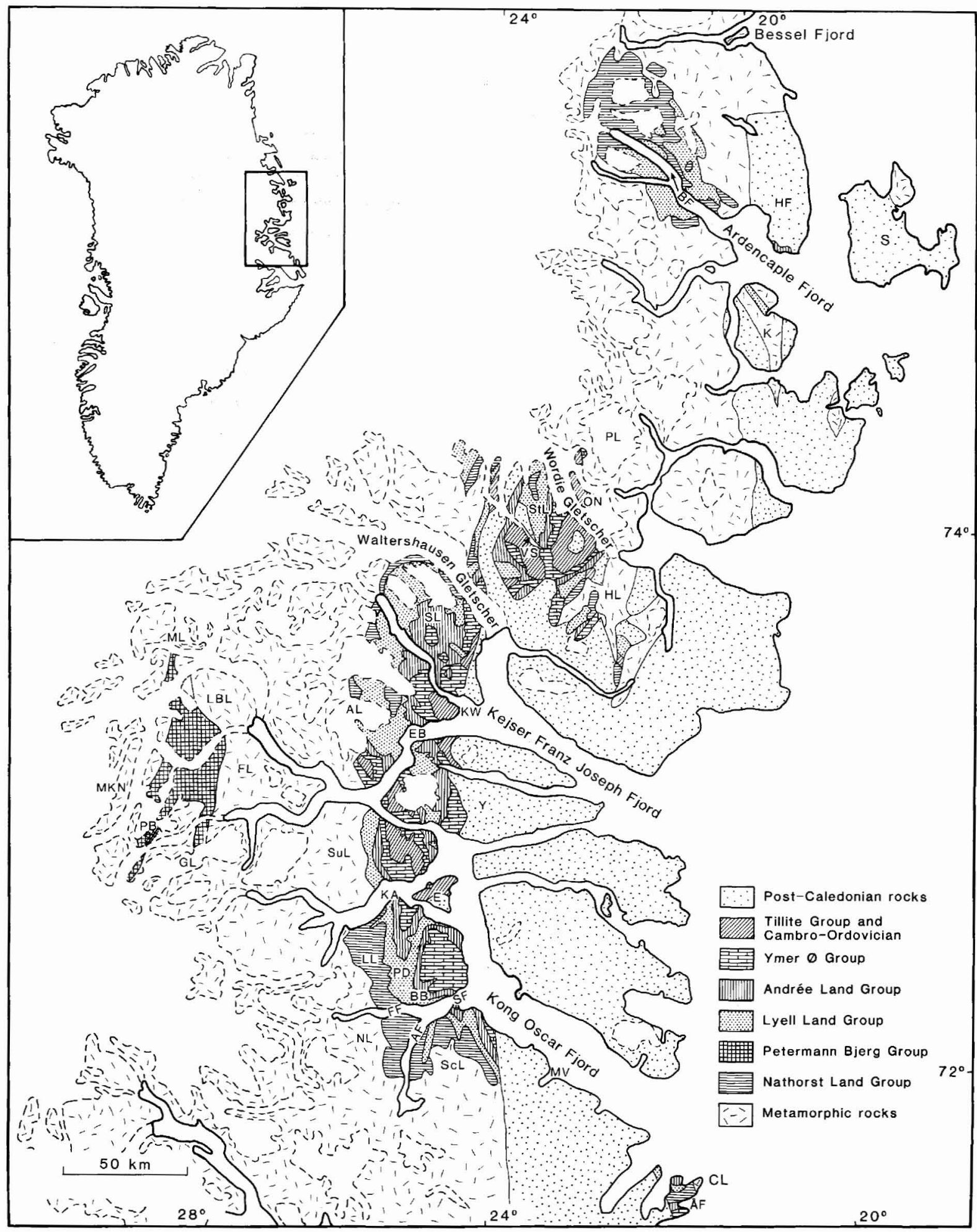

Fig. 1. Simplified geological map showing distribution of Eleonore Bay Supergroup outcrops in East Greenland with geographical place names used in text from north to south: BF: Bredefjord, HF: Hochstetter Forland, S: Shannon, K: Kuhn Ø, PL: Payer Land, ON: C. H. Ostenfeld Nunatak, StL: Steno Land, VS: Vibeke Sø, SL: Strindberg Land, KW: Kap Weber, AL: Andrée Land, K: Knækdalen, EB: Eleonore Bugt, Y: Ymer $\emptyset$, ML: J. L. Mowinkel Land, LBL: Louise Boyd Land, MKN: Martin Knudsen Nunatakker, FL: Frænkel Land, PB: Petermann Bjerg, GL: Goodenough Land, SuL: Suess Land, E: Ella Ø, KA: Kap Alfred, LL: Lyell Land, PD: Polhem Dal, BB: Berzelius Bjerg, FF: Forsblad Fjord, SF: Segelsällskapet Fjord, NL: Nathorst Land, AF: Alpefjord, ScL: Scoresby Land, MV: Mesters Vig, ÅF: Ålborg Fjord. The central fjord zone coincides with the Eleonore Bay Supergroup outcrop area between Alpefjord and Waltershausen Gletscher. 
this map strata of the Eleonore Bay Supergroup were mapped as Cambro-Silurian.

Following work in Greenland during 1926, Wordie (1927) suggested the name 'Franz Josef Beds' for Nathorst's 'Silurian' succession. Wordie did not describe the rocks further, but he mentioned that they were overthrust westward over the Archaean, and for the first time noted the possibility of Caledonian movements in East Greenland.

The main era of geological work in East Greenland was initiated by Lauge Koch's first Danish Expedition to East Greenland (1926-27). The most significant outcome of this expedition was a complete stratigraphic overview of Greenland (Koch, 1929b) and a monograph on the geology of East Greenland (Koch, 1929a). In the latter Koch defined the Eleonore Bay Formation and stated that the age was mainly Precambrian, although some Cambrian and Lower Ordovician strata were included in the formation at this early stage of exploration (Fig. 3).

In the years leading up to the Second World War scientific expedition activity in East Greenland was hectic. In 1929 both Lauge Koch's expedition and J. M. Wordie's Cambridge East Greenland Expedition were active in the area, to some extent in competition (see Backlund, 1930, p. 259 and Parkinson \& Whittard, 1931. p. 655), and in the years 1931-34 and 1936-38 Lauge Koch led major expeditions. The American Louise A. Boyd led expeditions to East Greenland in 1931, 1933 and 1938, but these gave only limited geological results concerning the Eleonore Bay Supergroup rocks (Boyd, 1935, 1948; Odell, 1939, 1944). An American geological field team from an expedition led by John K. Howard in 1933 mapped the western part of $Y$ mer $\emptyset$, which resulted in a subdivision of the 'Franz Josef Beds' into 10 formations (Cleaves \& Fox, 1935).

The principal results concerning the Eleonore Bay Supergroup succession stem from the British and Danish expeditions. The 1929 Cambridge East Greenland Expedition discovered a hitherto unknown sequence of sedimentary rocks in the westernmost land areas along the Inland Ice and named it the 'Petermann Series' after the mountain Petermann Bjerg west of the head of Kejser Franz Joseph Fjord (Wordie, 1930; Wordie \& Whittard. 1930; Parkinson \& Whittard, 1931). On a diagrammatic section through Kejser Franz Joseph Fjord, Whittard (in Wordie, 1930) showed the stratigraphic relationship of the 'Petermann Series' and the 'Franz Joseph Beds' with the intervening 'Metamorphic Complex' which they both unconformably overlie, but a more direct correlation between the two sedimentary successions was not proposed. However, it was noted that the 'Petermann Series' resembled the sediments discovered in 1912-13 in Dronning Louise Land $\left(77^{\circ} \mathrm{N}\right)$ by J. P. Koch and Alfred We- gener and described by Lauge Koch (1929a, p. 52). The latter had referred them partly to his Eleonore Bay Formation and partly to the Thule Formation of northern Greenland.

The Danish expeditions gave more detailed lithological and structural descriptions of the Eleonore Bay Formation, and a lithostratigraphic subdivision of this thick sedimentary sequence began to emerge. After the discovery of glacigenic sediments in the uppermost part of the Eleonore Bay Formation of Koch (1929a, b), Poulsen (1930) restricted the use of the Eleonore Bay Formation to the succession underlying his tillitic Cape Oswald Formation, thus constraining the age of the Eleonore Bay Formation as entirely Precambrian (Fig. 3). A thick sequence of previously unknown lower Eleonore Bay Formation strata was recognised by Backlund (1930) in the Alpefjord - Forsblad Fjord region, which he divided into a lower, a middle slaty and an upper multicoloured section. Based on work around Ymer $\emptyset$, Kulling (1930) divided the upper part of the formation into the 'Quartzite Series' and the 'Limestone-Dolomite Series', and this subdivision was further elaborated by Teichert (1933). It is to Teichert we owe the now classical subdivision of the upper Eleonore Bay Formation into the 'Quartzite Series' ('Quarzit Serie'), the 'Multicoloured Series' ('Bunte Serie') and the 'Limestone- Dolomite Series' ('Kalk-Dolomit Serie'). He also included the 'Petermann Series' in the Eleonore Bay Formation and suggested a correlation with the lower quartzitic part (Fig. 3). Finally he initiated the informal system of numbered 'bed-groups' ('Schichten' or 'Schicht-gruppen'), not completed until after the war by Eha (1953), and used up to the present time.

After the war, a systematic mapping campaign in East Greenland was initiated in 1946 and Lauge Koch's expeditions continued their work in the region until 1958. From this period originated a large number of descriptive and lithostratigraphic publications concerning the Eleonore Bay Formation (Bütler, 1948; Huber, 1950; Poulsen \& Wienberg- Rasmussen, 1951; Fränkl, 1951, 1953a, b; Katz, 1952; Eha, 1953; Wenk \& Haller, 1953; Haller, 1953, 1955, 1958; Sommer, 1957a, b; Zweifel, 1959). In the central fjord zone the original subdivision of the formation by Teichert (1933) became firmly established, but was slightly modified and extended with some new 'bed-groups' in the upper part of the 'Limestone-Dolomite Series' (Katz, 1952). Following work in the Scoresby Sund - Alpefjord region and in the inner fjord zone, the lower part of the formation was divided into a confusing wealth of new units (Fig. 3; see also Haller, 1971), some of which had a rather enigmatic relationship to the formation as originally defined. The concept of a "basal Series' was introduced by Fränkl (1953a) and expanded by Haller (1971, fig. 26), and included metasediments as 


\section{Teufelsschloss}

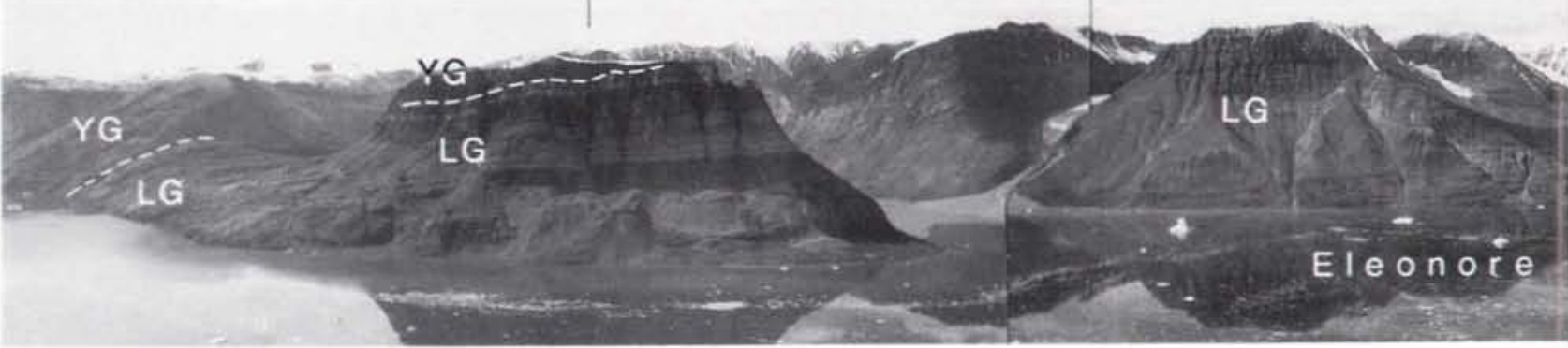

Fig. 2. Type locality of the Eleonore Bay Supergroup. View of Eleonore Bugt from Ymer $\emptyset$ across Kejser Franz Joseph Fjord. Height of Teuffelsschloss $1340 \mathrm{~m}$. LG: Lyell Land Group. YG: Ymer $\emptyset$ Group, AG: Andrée Land Group. TG: Tillite Group and younger Cambro-Ordovician sediments.

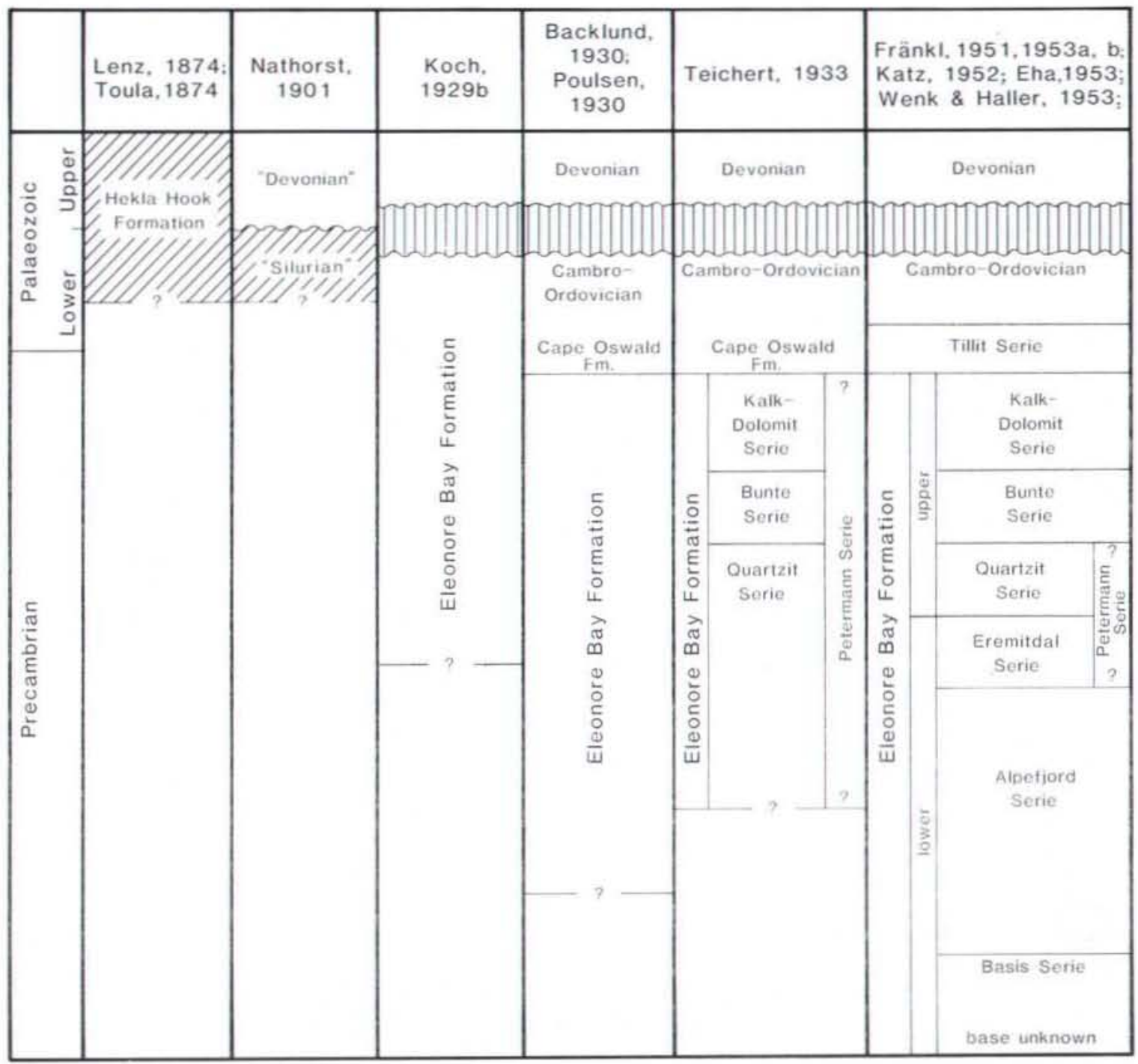

Fig. 3. Previous and present lithostratigraphic schemes used in connection with the Eleonore Bay Supergroup succession. The hatching in the two first columns indicates successions including the later Eleonore Bay Formation. *Henriksen \& Higgins (1976). however, did not include the 'Basal Series' of Haller (1971) in the Eleonore Bay Group. 
well as granites and gneisses supposed to be migmatised and granitised equivalents of the Eleonore Bay Formation (Fig. 3).

In an attempt to modernise the lithostratigraphic terminology of the Eleonore Bay Formation, Katz (1961) proposed a formal lithostratigraphical scheme in which he raised the formation to group status and defined four new formations within the group (Fig. 3). However, this scheme never gained general acceptance, and only the change to group status survived.

The work of the East Greenland Expeditions carried out between 1926 and 1958 was compiled by Haller and resulted in a geological map at 1:250 000 of the region between $72^{\circ}$ and $76^{\circ} \mathrm{N}$ in East Greenland (Koch \& Haller, 1971) and a 1:1 000000 map of North-East Greenland (Haller, 1983). The geological results were reviewed and interpreted by Haller (1971) in his comprehensive book on the East Greenland Caledonides. With all these new data on the Eleonore Bay Supergroup succession, correlations with other Upper Proterozoic sequences in the North Atlantic region became pertinent. The correlation to the Hecla Hoek succession (previously termed the Hekla Hook formation), already proposed by Toula (1874), became established (Harland et al., 1966), and a plate-tectonic framework for the region was suggested (Harland \& Gayer, 1972; Harland, 1975).

The next major phase in the study of the East Greenland Caledonides was a mapping programme in the Scoresby Sund area and subsequently north of Mesters Vig conducted by the Geological Survey of Greenland (GGU) in 1968-78. During this, the Lower Eleonore Bay Group in Alpefjord and the rather poorly known succession in Canning Land were investigated (Caby, 1972.
1976; Bertrand-Sarfati \& Caby, 1976). An acritarch study was carried out (Vidal, 1976, 1979) and some geochemical analyses were made of carbon and oxygen isotopes (Schidlowski et al., 1975).

For many years it had been debated whether the lower boundary of the Eleonore Bay Group was a thrust (e.g. Teichert, 1933; Parkinson \& Whittard, 1935; Odell, 1939. 1944 ) or whether the boundary had a more gradational metamorphic transition (e.g. Wegmann, 1935; Wenk \& Haller, 1953; Haller, 1971). In order to solve this problem, the relationships between the Archaean - Middle Proterozoic basement gneiss complexes, the medium- to high- grade metasediments and the Eleonore Bay Group sediments were the target of special studies during the GGU campaign (Caby, 1976; Friderichsen \& Higgins, 1976: Higgins et al., 1977, 1981; Rex \& Gledhill, 1981; Peucat et al., 1985; Higgins, 1988).

In the 1980s several small American and British expeditions studied various special aspects of the uppermost part of the Eleonore Bay Supergroup. This resulted in some detailed sedimentological work (Hambrey, 1989; Herrington \& Fairchild, 1989; Swett \& Knoll, 1989). descriptions of different microfossil assemblages (Knoll et al., 1986a; Green et al., 1987, 1988. 1989) and a chemostratigraphic correlation of the Eleonore Bay Supergroup with equivalent strata on Svalbard (Knoll et al., 1986b).

In addition to the basic geological research activities summarised above, a mineral prospecting programme was carried out by Nordisk Mineselskab (Northern Mining Company) from 1952 to 1984: this has been reviewed in detail by Harpoth et al. (1986).

\section{Terminology}

There is some ambiguity in the use of the terms shelf and platform, especially in mixed siliciclastic-carbonate depositional environments (cf. Read, 1982). In this paper the term shelf is used as a general term for a nearly flat area extending from the shoreline to the shelf/slope break. Inner shelf is the coastal area above normal wave base, and outer shelf is the area of quiet deposition only affected by occasional storms. Carbonate platform is used in the sense of Read (1982) as a unifying term for carbonate shelves and ramps.

In the lithological descriptions protolithic terms are used throughout, e.g. the term sandstone is used in preference to quartzite, and mudstone instead of shale.
In this paper the English names for the various stratigraphic units are used throughout: e.g. 'bed-group' is used instead of the German term 'Schicht-gruppe' and 'Upper Argillaceous - Arenaceous Series' is used instead of 'Obere Tonig-sandige Serie'.

The chronostratic scale used here for the Upper Proterozoic is mainly based on Harland et al. (1989). It differs from that previously used in the area (Vidal, 1976, 1979; Bertrand-Sarfati \& Caby, 1976), and the correlation between the scales is shown in Fig. 4. 
Fig. 4. Correlation of chronostratic scales used by various authors in the region. Note that in certain parts of the scheme, biostratigraphic dates are denoted as different epochs. Edi: Ediacara: Var: Varanger.
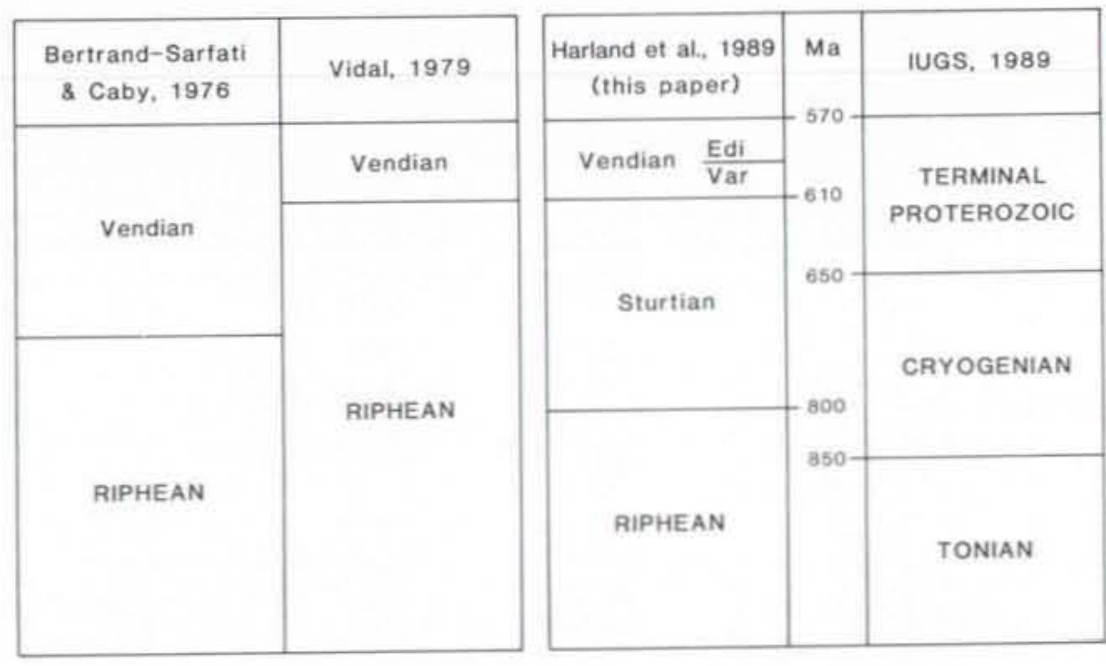

\section{Lithostratigraphy}

In this paper, the Eleonore Bay Supergroup is formally proposed and divided into five groups (Fig. 3); definition of the groups commences with the oldest strata.

\section{Eleonore Bay Supergroup}

new status

History. The Eleonore Bay Supergroup is identical to the Eleonore Bay Group as described by Henriksen \& Higgins (1976). Thus, it does not contain rocks assigned to the 'basal Series' by Haller (1971) (Fig. 3), but includes exclusively rocks above the décollement surface described by Higgins et al. (1981).

Name. From the bay Eleonore Bugt in Kejser Franz Joseph Fjord (Fig. 2); the locality where the succession was originally described (Toula, 1874; Koch, 1929a).

Type area. The type area is the central fjord zone between $72^{\circ} \mathrm{N}$ and $74^{\circ} \mathrm{N}$, where both the (tectonic) base and the top of the supergroup are exposed and where the succession is typically developed (Fig. 1).

Thickness. The combined preserved thickness of the Eleonore Bay Supergroup reaches a maximum of $c .16000$ $m$ in the southern part of the central fjord zone (Fig. 5). The true thickness is not known since the lower boundary is tectonic.

Distribution. Rocks of the Eleonore Bay Supergroup can be found between Canning Land in the south-east $\left(71^{\circ} 30^{\prime} \mathrm{N}\right)$ and Bessel Fjord in the north $\left(76^{\circ} \mathrm{N}\right)$. The main area of outcrop is the central fjord zone (Fig. 1).

Dominant lithology. The Eleonore Bay Supergroup can be divided into three parts reflecting the evolution from siliciclastic deposits over mixed siliciclastic-carbonate sediments to carbonate deposits (Fig. 5). The lower siliciclastic section is up to $13000 \mathrm{~m}$ thick and consists of thick interbedded packages of pale quartzose sandstone and dark to purplish mudstone. The transitional mixed section is up to $1200 \mathrm{~m}$ thick and shows an alternation of thick units of dark limestone, purple dolomitic limestone, pale stromatolitic dolomite and dark to pale sandstones. The upper carbonate section (up to about $1500 \mathrm{~m}$ thick) is dominated by dark limestone with some thin intervals of variegated dolomite and pale stromatolitic or strongly brecciated dolomite.

Depositional environment. The deposits of the lower sandstone-dominated part of the Eleonore Bay Supergroup were laid down in both continental and shallow marine shelf environments. The upper carbonate dominated part of the supergroup represents platform and slope deposits (for details see below).

Boundaries. The lower contact is placed where sediments and metasediments of the Eleonore Bay Supergroup overlie migmatites and schists. Based on isotopic dating and field observations Higgins et al. (1977, 1981) and Bengaard (1989) proposed that the contact throughout the central fjord zone is associated with a major décollement surface, and suggested that the apparent transitional na- 


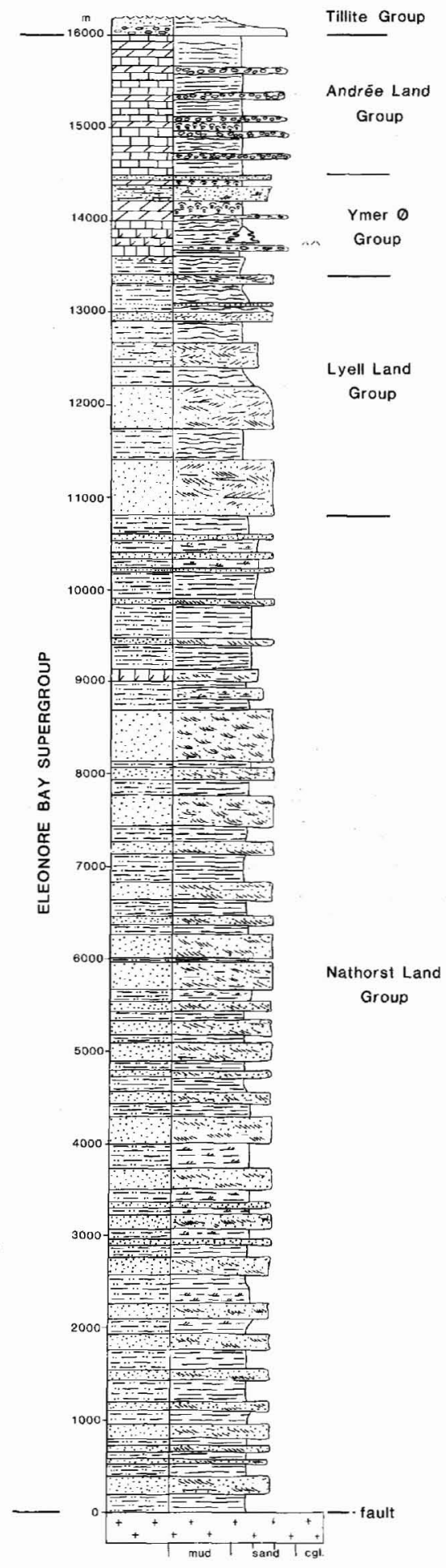

ture of the contact zone results from movements on this surface during progressive Caledonian metamorphism, and common emplacement of granite intrusions obscuring the nature of the original contact (Fig. 6). However,
Fig. 5. Generalised composite section of the Eleonore Bay Supergroup from the central fjord zone. Partly based on Katz (1952), Fränkl (1953a), Caby \& Bertrand-Sarfati (1988) and Herrington \& Fairchild (1989).

\section{LEGEND}

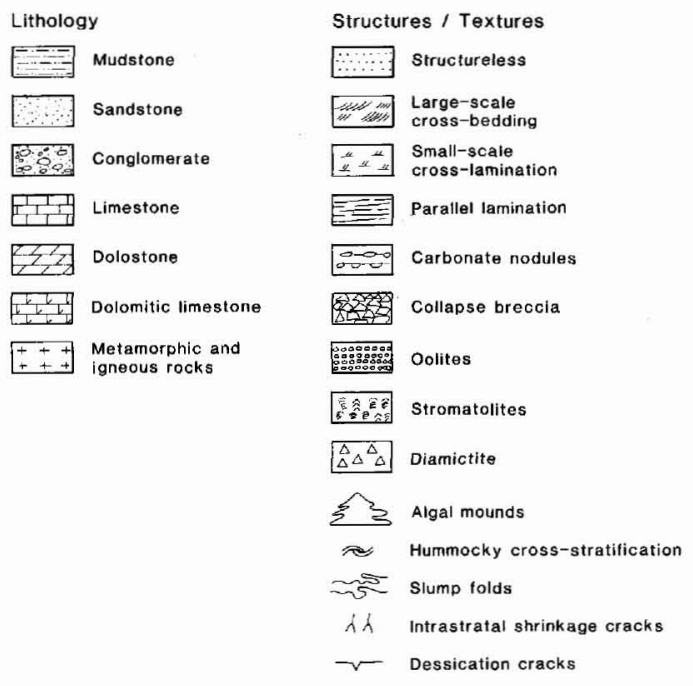

other workers (Caby, 1976; Caby \& Bertrand- Sarfati, 1988) favour the interpretation of Haller $(1958,1971)$ and others that the contact is of a transitional nature, passing downwards from non-metamorphic deposits of 
the lower Eleonore Bay Supergroup through high-grade metasediments into pelitic gneisses and migmatites. Later work in the Bredefjord - Ardencaple Fjord region has confirmed the essential tectonic nature of the lower boundary (Henriksen et al., 1989; Soper \& Higgins, 1993).

In many areas the supergroup forms the top unit at present exposure levels. Where the upper contact is exposed, the nature of the boundary to the overlying Tillite Group is variable. The Tillite Group generally rests on Formations AL6 and AL7 (Andrée Land Group; Fig. 27) with a sharp or rapidly transitional contact, or it is a thrust (Fig. 7A). In the southern areas the Tillite Group may rest on an erosion surface of Formation AL5 or lower. The boundary is easily defined as the change from carbonate to diamictite (Fig. 7B; Hambrey \& Spencer, 1987). On southern Hochstetter Forland the Eleonore Bay Supergroup is overlain with an angular unconformity by Jurassic sediments (Sommer, 1957b; Surlyk, 1978). In the southern outcrop area, the Devonian Old Red Sandstone basin of East Greenland is both faulted against and in sedimentary contact with the Eleonore Bay Supergroup (Fig. 8; Larsen \& Bengaard, 1991; Olsen \& Larsen, 1993).

Subdivisions. The Eleonore Bay Supergroup is divided into five groups which, from bottom to top, are the Nathorst Land Group, the Petermann Bjerg Group, the Lyell Land Group, the Ymer $\emptyset$ Group and the Andrée Land Group. As the names suggested by Katz (1961) never have been generally used, the group names proposed herein have been chosen from land areas where the groups are typically developed and easily accessible. The Petermann Bjerg Group has not been given a new land area name, as this geographic name has been used since the discovery of the succession in 1929 by J. M. Wordie's Cambridge East Greenland Expedition.

Age. The lower age limit of the Eleonore Bay Supergroup is poorly constrained. Biostratigraphic evidence only indicates a general Riphean age for the lower part of the succession (see below). The Nathorst Land Group contains detrital zircon with a lower intercept $\mathrm{U} / \mathrm{Pb}$ discordia age of $1162 \pm 36 \mathrm{Ma}$ and detrital muscovite with a $\mathrm{K} / \mathrm{Ar}$ age of $1030 \pm 22 \mathrm{Ma}$ (Peucat et al., 1985). Thus rocks metamorphosed during the Grenvillian Orogeny must have been present in the Nathorst Land Group source area. The deposition of the group must have started sometime after the end of this orogeny, which in East Greenland is estimated at c. $950 \mathrm{Ma}$ (Steiger et al., 1979).

Lead isotope studies from syn-diagenetic stratiform copper mineralisation within the Lyell Land and Ymer Ø Groups in Strindberg Land, Ymer $\emptyset$ and Canning Land have indicated a primary mineralisation age of $680 \pm 65$ Ma (Jensen, 1993).

The upper age limit of the Eleonore Bay Supergroup is better defined as the overlying Tillite Group is of Varanger age (610 Ma; Harland et al., 1989). Sedimentological data suggest that there is little or no hiatus between the two units (Hambrey \& Spencer, 1987; Herrington \& Fairchild, 1989; Moncrieff, 1989). On the basis of micropalaeontological investigations, Vidal (1979) proposed a major hiatus between the Eleonore Bay Supergroup and the Tillite Group, but more recent data do not support this (G. Vidal, personal communication, 1991).

Although sedimentation probably started considerably later than the end of the Grenvillian Orogeny, the maximum span of time of the Eleonore Bay Supergroup is from late Riphean ( $950 \mathrm{Ma}$ ) to the Sturtian-Vendian boundary $(610 \mathrm{Ma})$ with apparently only minor internal non-depositional events (Fig. 3).

\section{Nathorst Land Group}

new

History. Rocks belonging to this group were first described by Backlund (1930) from the Forsblad Fjord region, and he referred to them as the "lower section of the Eleonore Bay Formation'. This succession was later described in more detail by Fränkl (1951; 1953a, b) and Sommer (1957a) from the Alpefjord - Forsblad Fjord region and from Andrée Land. Fränkl (1951) divided the succession into a lower 'Alpefjord Series' and an upper 'Eremitdal Series' (Fig. 3). As defined here, the Nathorst Land Group includes both the 'Alpefjord Series' and the 'Eremitdal Series' and corresponds to the Lower Eleonore Bay Group of Henriksen \& Higgins (1976) (Fig. 3). It encompasses the 'Lower Arenaceous - Argillaceous Series', the 'Calcareous-Argillaceous Series' and the 'Upper Argillaceous - Arenaceous Series' of Koch et al. (in Fränkl, 1953a, table 6). The Nathorst Land Group likewise corresponds to the Alpefjord Formation of Katz (1961) (Fig. 3), who had also assigned new names to the rather cumbersome subdivision of the Lower Eleonore Bay Group ('Lower Quartzite member', 'Middle Limestone member' and 'Upper Quartzite member').

Further subdivisions of the Nathorst Land Group have earlier been proposed by Fränkl (1951) who defined 16 bed-groups (a-q) within the 'Alpefjord Series', and by Sommer (1957a) who in Lyell Land recognised 19 bedgroups (a-t) within the 'Upper Argillaceous - Arenaceous Series'. Some of these bed-groups or associations of them have been photogrammetrically mapped in Nathorst Land and Scoresby Land by Bengaard (1992a). 
Fig. 6. Contact relationship between the Eleonore Bay Supergroup and schists along the northern shores of Forsblad Fjord. T-T thrust contact between Eleonore Bay Supergroup (Nathorst Land Group. NG) and older metamorphic rocks. Granite intrusives (gi) and granite sheets (gs) occur close to the contact obscuring detailed relationships. Height of mountain in centre of picture is e. $1700 \mathrm{~m}$. Lower part of Lyell Land Group (LG) is seen to the east.
Name. After Nathorst Land where most of the group is well-exposed.

Type area. The coastal cliffs of Alpefjord and Forsblad Fjord (Figs 1, 9).

Thickness. Based on data collected by B. Evans, Haller (1971) calculated a total thickness of $9500 \mathrm{~m}$ in Nathorst Land and Scoresby Land. Caby \& Bertrand-Sarfati (1988) measured a total thickness of $c .11000 \mathrm{~m}$ in the cliffs of Alpefjord and Forsblad Fjord (Fig. 10), corrected for an overestimate of approximately $5 \%$ in the lower formation, due to overall extensional cleavage and local faulting. Based on a photogrammetric interpretation,

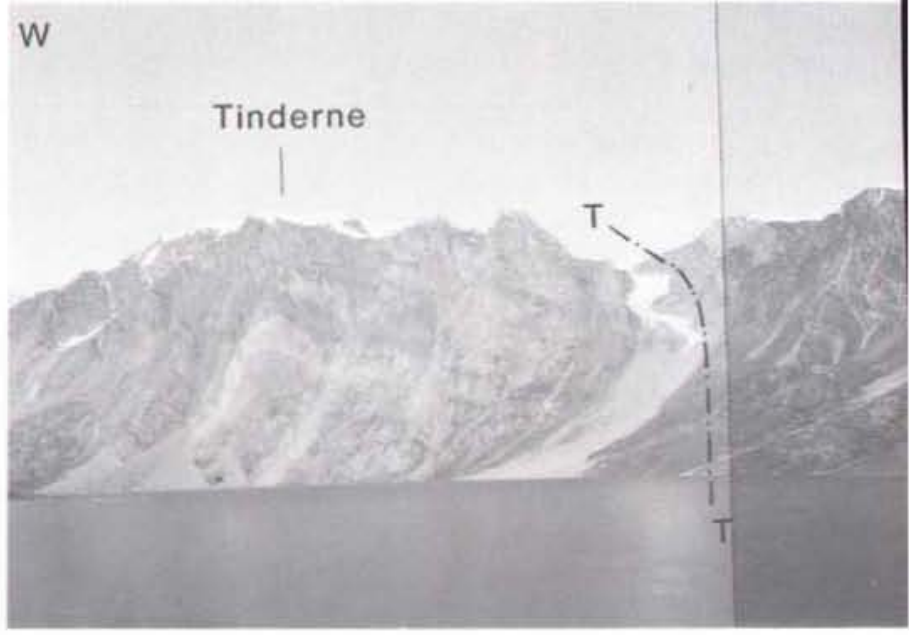

Bengaard (1992a) found that in Scoresby Land relatively large variations in thickness occur within the Nathorst Land Group, particularly in the central part of the group. In the Bredefjord - Ardencaple Fjord region it is estimated that at least $2000 \mathrm{~m}$ of the upper part of the group is present (Sønderholm et al., 1989; A. K. Higgins, personal communication, 1991).

Distribution. The group is mainly preserved in the region between Nathorst Land and southern Lyell Land, and to the north in the Bredefjord - Ardencaple Fjord region. Smaller remnants are preserved in Andrée Land, Strindberg Land and in the region between Waltershausen Gletscher and Wordie Gletscher (Fig. 1). According to

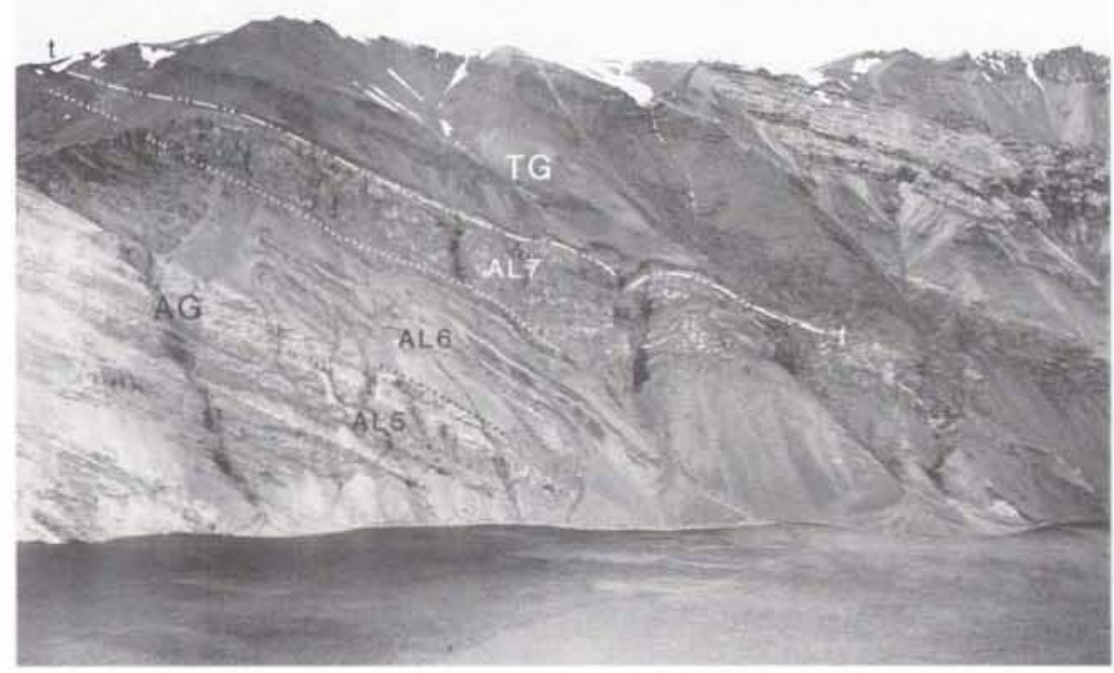

Fig. 7. A. Thrust contact between Eleonore Bay Supergroup (Andrée Land Group. AG. Formations ALS-7) and Tillite Group (TG) along Eleonore Bugt south of Kap Weber. 


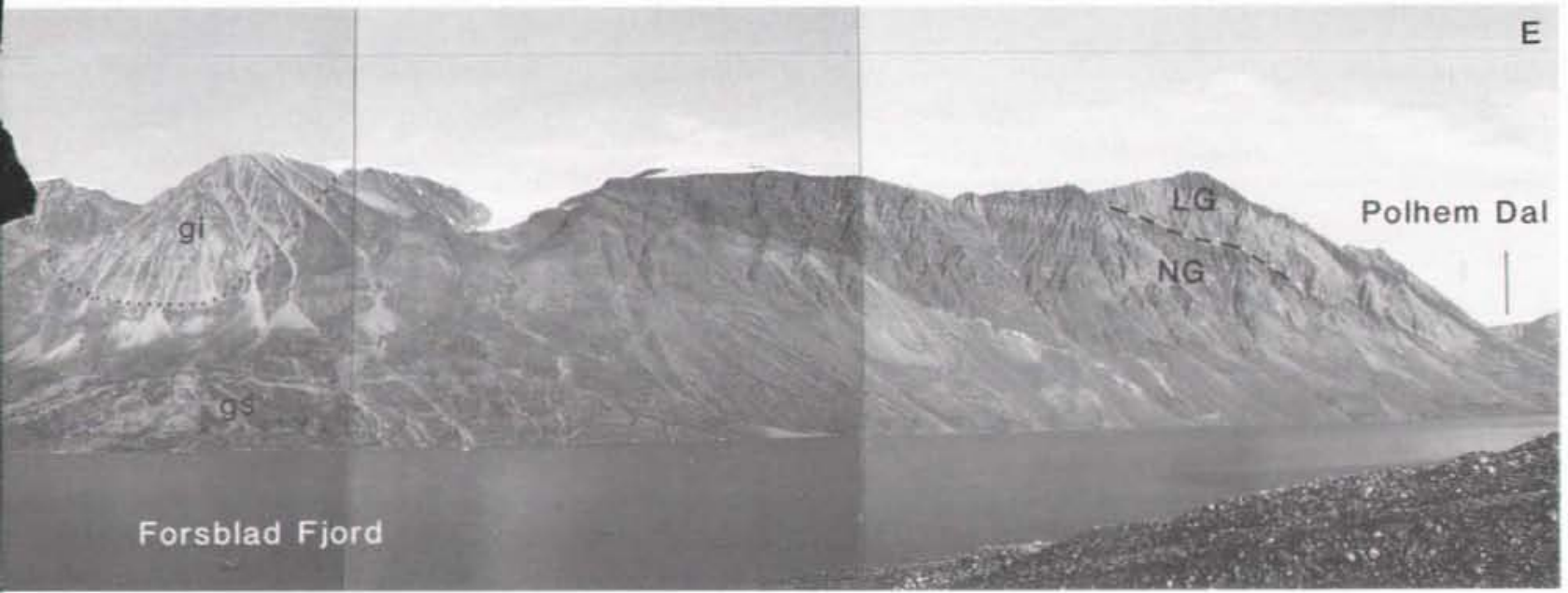

Caby (1972) at least $2000 \mathrm{~m}$ of the Nathorst Land Group is preserved in Canning Land, but intense faulting and mylonitisation make estimates of thickness and correlation very difficult in this area.

Dominant lithology. The following summary is based on descriptions by Fränkl (1951: 1953a, b), Katz (1961). Haller (1971), Caby (1976), Henriksen \& Higgins (1976) and Caby \& Bertrand-Sarfati (1988). The group consists of a dark grey-green to brownish weathering succession of alternating units, a few metres to several hundred mutres thick. These comprise quartzose sandstones, banded sandstones and mudstones, black silty mudstones and occasional calcareous intercalations. In many areas the deposits have been affected by recrystallisation and deformation, particularly in the lower part of the group where the metamorphic grade reaches amphibolite facies. Sedimentary structures and original textures are consequently often poorly preserved (e.g. Sønderholm et al., 1989). Quartzose sandstone units are tabular or lenticular in outline and are dominated by fine- to medium-grained sandstone, with coarse-grained sandstone and granules being of only local importance, particularly in the upper part of the group. Within the sandstones large-scale planar and trough cross-bedding, as well as recumbent crossbedding have been recorded. The banded sandstones and mudstones are dominated by flaser and lenticular bedding, small-scale cross-lamination and climbing ripple lamination. Black mudstones contain abundant pyrite and show a fine parallel lamination, sometimes exhibiting
Fig. 7. B, Close-up of sharp erosional contact between Formation AL6 and Tillite Group west of Vibeke Ss; (d) dolomite raft from the underlying Andrée Land Group.

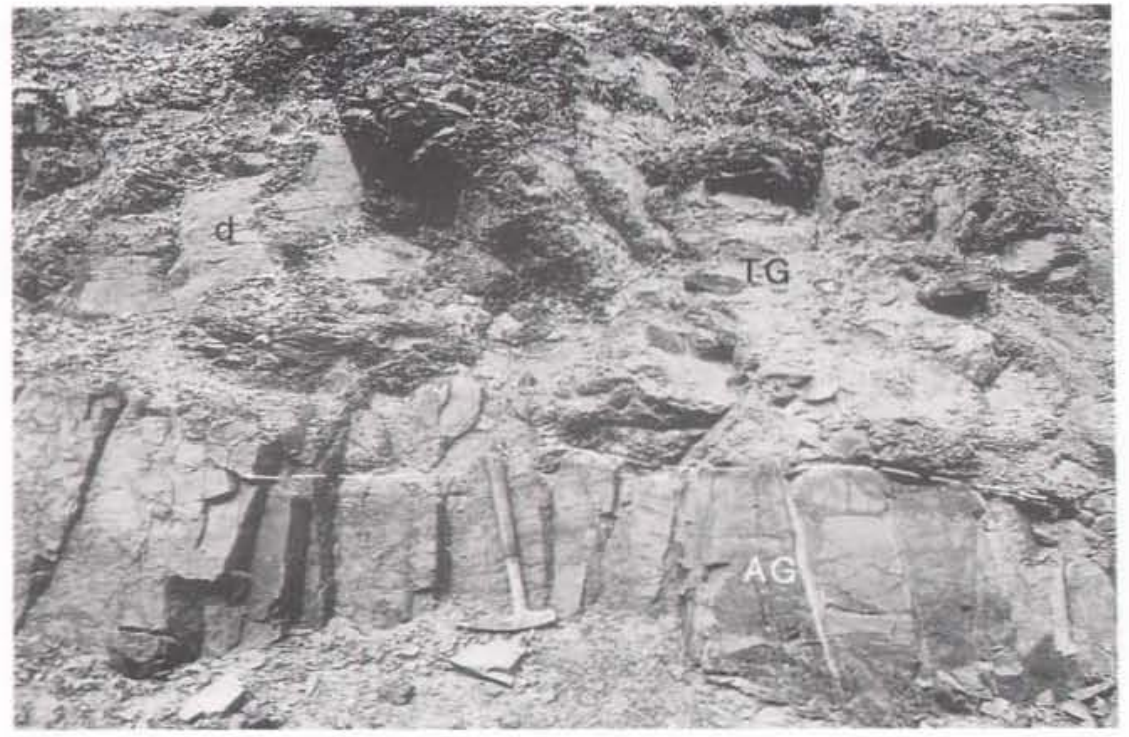




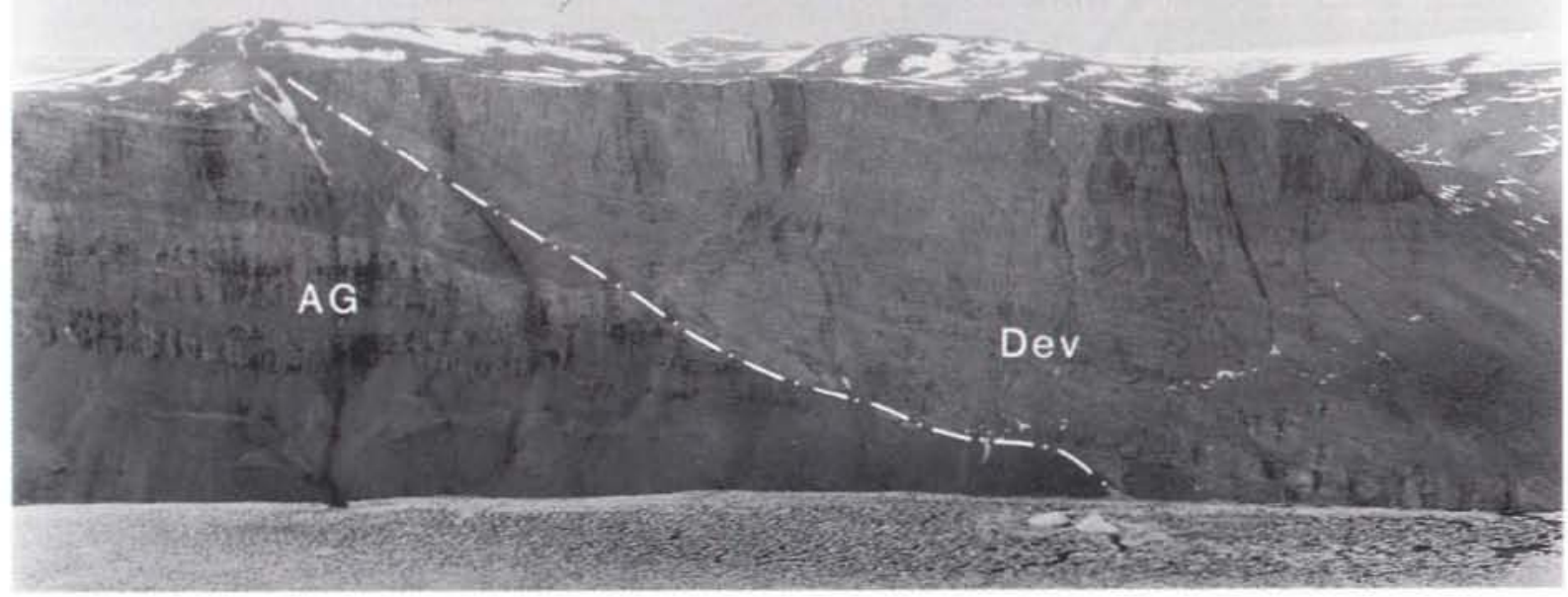

Fig. 8. Fault contact between Eleonore Bay Supergroup (Andrée Land Group, AG) and Devonian sediments (Dev) as exposed along southern Strindberg Land, Geologfjord. Height of cliffs $c .1000 \mathrm{~m}$.

normal grading. Carbonate deposits are mainly found in a $150 \mathrm{~m}$ thick interval in the upper half of the group (Fig. 10 ) and consist of both limestone and dolomite. Parallel lamination, possibly of algal origin, and large-scale cross-bedding are preserved in the carbonates. Desicca- tion cracks are widespread within the group, both within siliciclastic and carbonate deposits.

The Nathorst Land Group may be separated into three formations in the type area: a lower formation with approximately equal amounts of sandstones and more fine-

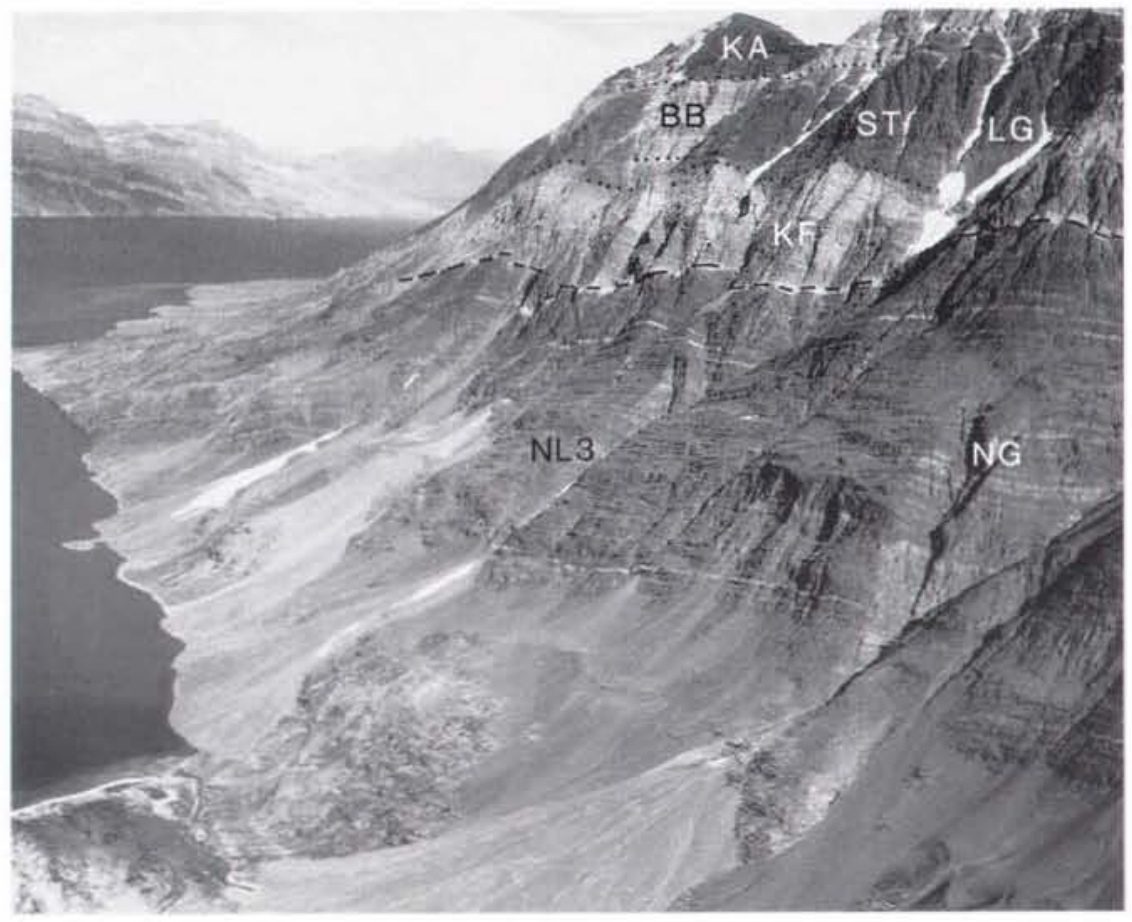

Fig. 9. Upper part of Nathorst Land Group (NG, Formation NL3) with contact to Lyell Land Group (LG) as exposed on the eastern coast of Alpefjord. KF: Kempe Fjord Formation (c. $600 \mathrm{~m}$ thick): ST: Sandertop Formation; BB: Berzelius Bjerg Formation; KA: Kap Alfred Formation. 
grained deposits, showing a rough coarsening upward trend; a middle carbonate formation; and an upper formation dominated by heterolithic sandstone and mudstone deposits, with local intercalations of dolomite lenses and streaks (Fig. 10).

Depositional environment. Information regarding depositional setting of the Nathorst Land Group is scarce, and at present no detailed sedimentological analysis of the group has been made. Caby \& Bertrand-Sarfati (1988) tentatively proposed a continental, mainly fluvial origin for the lower two intervals and a shallow water marine origin for the upper interval. For Canning Land, Caby (1972) suggested that deposition of the Nathorst Land Group may have occurred on a vast delta-plain or on a shallow subtidal shelf.

Boundaries. The lower contact corresponds to the lower contact of the Eleonore Bay Supergroup and accordingly is described above. The upper contact throughout the region is placed where dark green silty mudstones of the Nathorst Land Group are overlain by a more than $500 \mathrm{~m}$ thick, monotonous succession of white weathering sandstones of the basal Lyell Land Group. The upper contact is transitional, forming a 5-10 m thick coarsening upwards unit in the top of the Nathorst Land Group (Fig. 11); however, at a distance the contact appears sharp (Figs 6, 9). The boundary is well exposed in Scoresby Land (Fig. 9), Lyell Land, Andrée Land, Strindberg Land and in the Bredefjord - Ardencaple Fjord region (Fig. 12). In Canning Land the boundary between the Nathorst Land Group and the Lyell Land Group is invariably a thrust contact (Caby, 1972).

Fauna and geological age. Eleven samples from the Nathorst Land Group have been processed for acritarchs (Vidal, 1976, 1979). These yielded Synsphaeridium sp. and some carbonised, flattened sphaeromorphs which could be ascribed to $C$. circularis. However, neither of them are age diagnostic.

Subdivision. At present the group is informally divided into three formations: Formation NL1 (corresponding to the 'Lower Arenaceous - Argillaceous Series'), Formation NL2 (corresponding to the 'Calcareous-Argillaceous Series') and Formation NL3 (corresponding to the 'Upper Argillaceous - Arenaceous Series') (Figs 3, 10).

Fig. 10. Generalised sedimentological log of the Nathorst Land Group modified from Fränkl, 1951, Haller, 1971 and Caby \& Bertrand-Sarfati, 1988. For legend see Fig. 5.

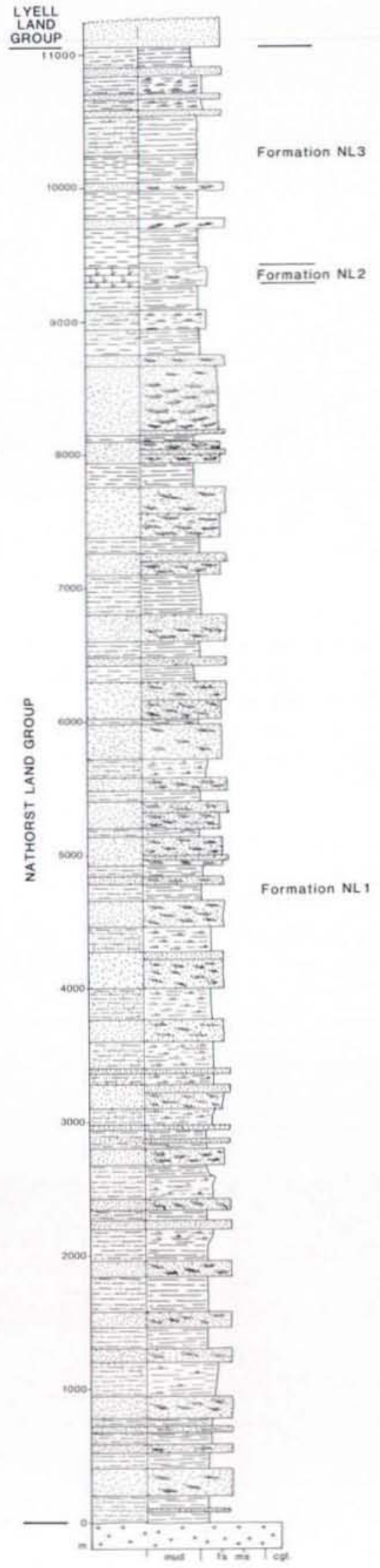




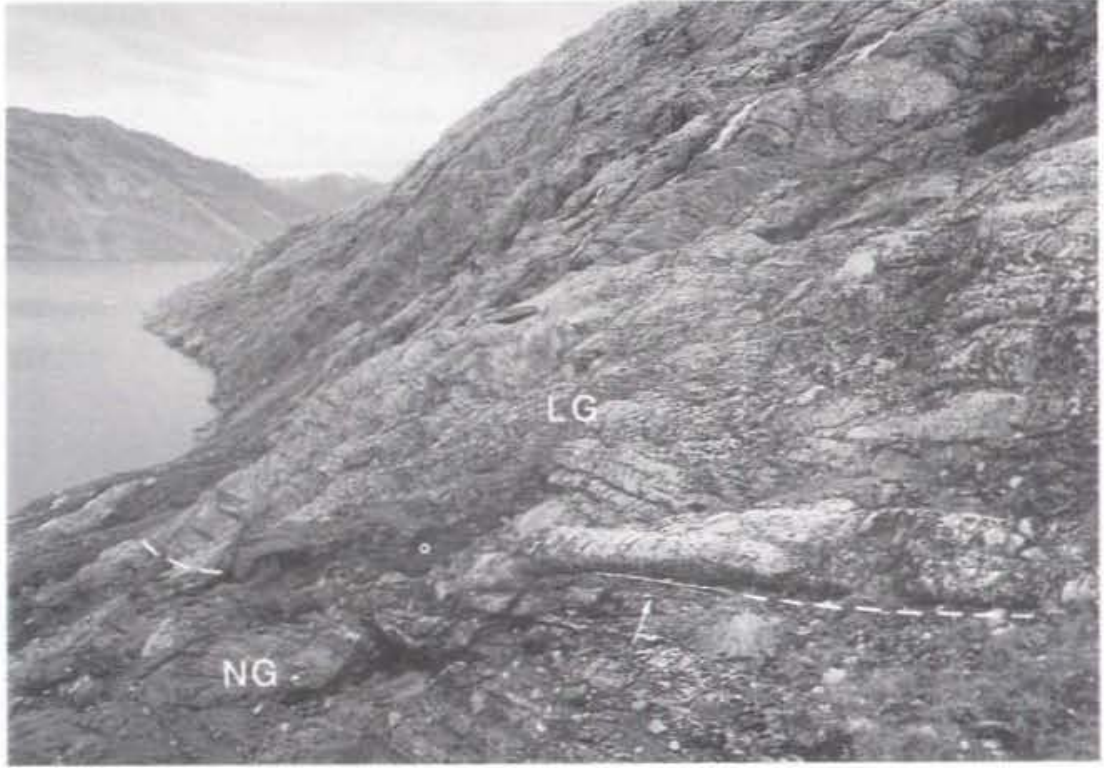

Fig. 11. Detail of sharp boundary between Nathorst Land and Lyell Land Groups. Ruler (at arrow) in contact is $2 \mathrm{~m}$ long. Northern Lyell Land, just west of Kap Alfred.

\section{Petermann Bjerg Group new}

History. The sedimentary succession exposed to the west of the central metamorphic complex around Petermann Bjerg (Fig. 1) was discovered in 1929 and named the 'Petermann Series' (Wordie \& Whittard. 1930). More detailed studies of the 'Petermann Series' were subsequently carried out by Odell $(1939,1944)$, Huber (1950) and Wenk \& Haller (1953). The most comprehensive study of the 'Petermann Series' so far is that of Wenk \& Haller. They established the areal extent of the 'series' and subdivided it into six units: the "Mystery Quartzite
Series', the 'Phyllite Series', the 'Layered QuartziteSlate-Dolomite Series', the 'Shoulder Quartzite- Slate Series', the 'Summit Quartzite Series' and the 'Synclinal Quartzitic Sandstone-Shale Series' (Fig. 13).

Although separated from the Eleonore Bay Supergroup sediments to the east by the central metamorphic complex, early workers (Wordie \& Whittard, 1930; Teichert, 1933; Odell, 1939. 1944: Huber, 1950) assumed a similar age for both the deposits of the Petermann Bjerg Group and the Eleonore Bay Supergroup sediments in the central fjord zone, but Wenk \& Haller (1953) were the first to propose a more detailed correlation between the two areas, based on lithological similarities and tectonic rela-

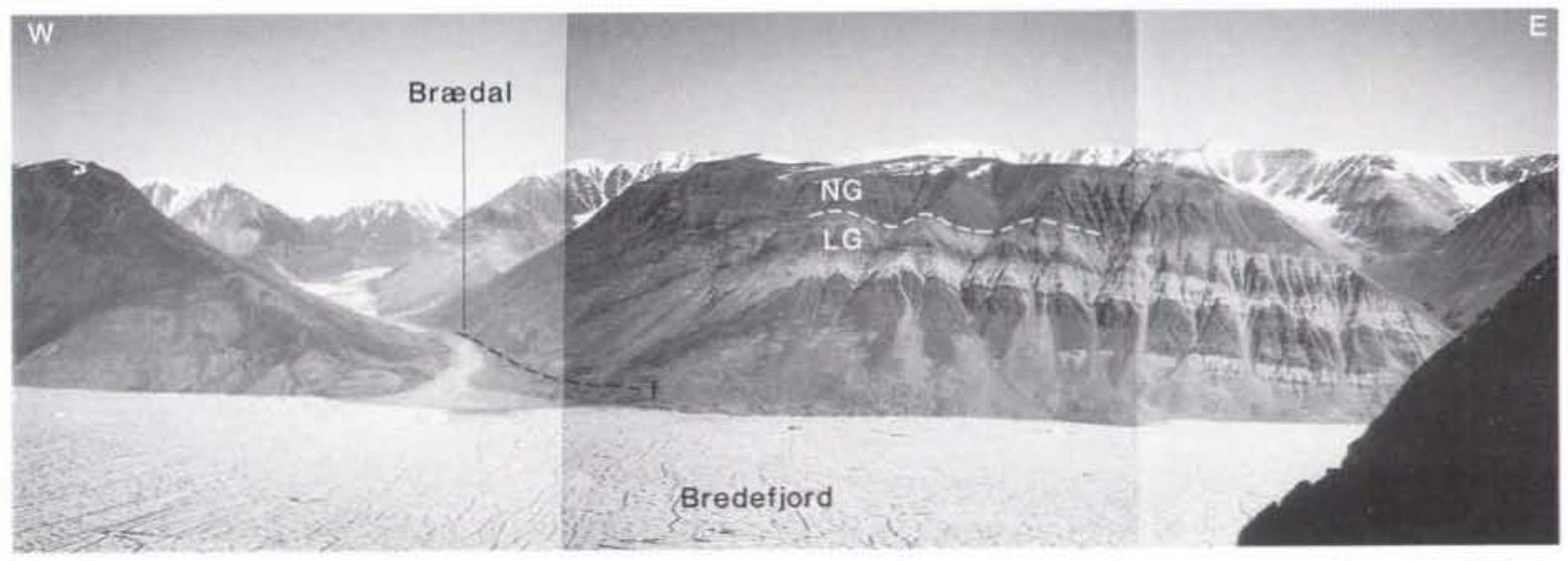

Fig. 12. Contact between Nathorst Land Group (NG) and Lyell Land Group (LG) as exposed along the northern shore of Bredefjord. The succession east of Bradal corresponds to the 'Bradal Quartzites' of Sommer (1957b). However, it has been shown that it is a folded (trace of fold axis, $f$ ) and inverted part of the Nathorst Land and Lyell Land Groups. 
Fig. 13. Previous and present lithostratigraphic subdivision of the Petermann Bjerg Group.

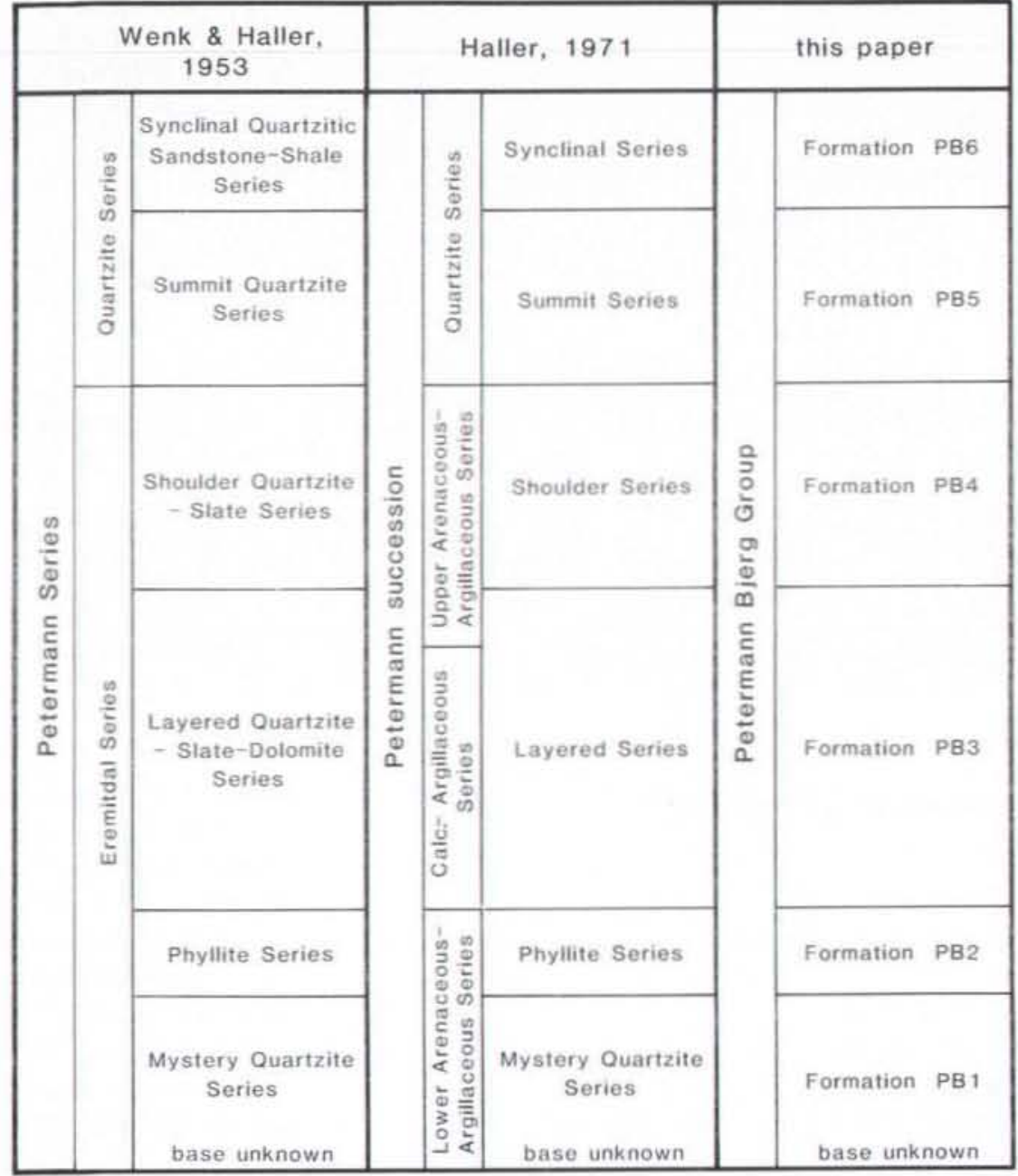

tionships. They considered the lower four units to correspond to the 'Eremitdal Series' and the upper two units to correspond to the 'Quartzite Series' (Figs 3, 13). Haller (1971) appears to have discarded the name 'Petermann Series' and described the 'Petermann succession' as forming part of the entire Lower Eleonore Bay Group and the 'Quartzite Series' of the Upper Eleonore Bay Group (Figs 3, 13).

In this paper the Late Precambrian sediments assigned by Wenk \& Haller (1953) to the 'Petermann Series' are defined as the Petermann Bjerg Group (Figs 3, 13) and considered to correlate with the Eleonore Bay Supergroup east of the metamorphic complex (Wenk \& Haller, 1953; Haller, 1971; Henriksen \& Higgins, 1976; Higgins et al., 1981). This division is maintained as lithological patterns found east and west of the central metamorphic complex are not directly comparable and the precise correlation of units is still uncertain.
Name. After the prominent mountain Petermann Bjerg in the nunatak region west of the central metamorphic complex (Figs 1, 14).

Type area. Western Frænkel Land and western Louise Boyd Land (Fig, 1).

Thickness. The preserved sedimentary succession was measured by Wenk \& Haller (1953) to reach a maximum thickness of $6300 \mathrm{~m}$ in the area around Knakdalen (Fig. 1). Higgins et al. (1981) recorded about $1300 \mathrm{~m}$ more of the basal unit of the group preserved in Louise Boyd Land, such that the cumulative thickness of the group in the type area is about $7600 \mathrm{~m}$ (Fig. 15).

Distribution. The group is only preserved west of the central metamorphic complex. It is widely distributed in western Frankel Land, Louise Boyd Land and Goodenough Land (Fig. 1). Small remnants are shown on the 


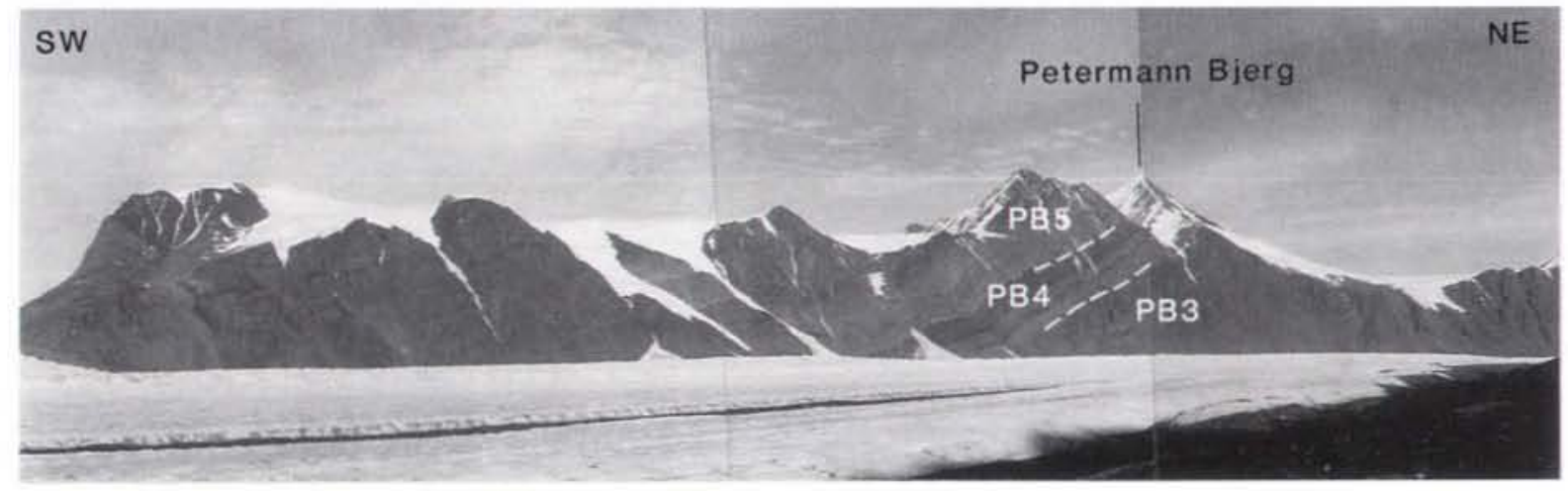

Fig. 14. View across Nordenskjöld Gletscher towards Frankel Land showing Petermann Bjerg Group (Formations PB3-5) with Petermann Bjerg $(2940 \mathrm{~m})$ in background. Height of cliff- section in middle part of picture is around $1300 \mathrm{~m}$.

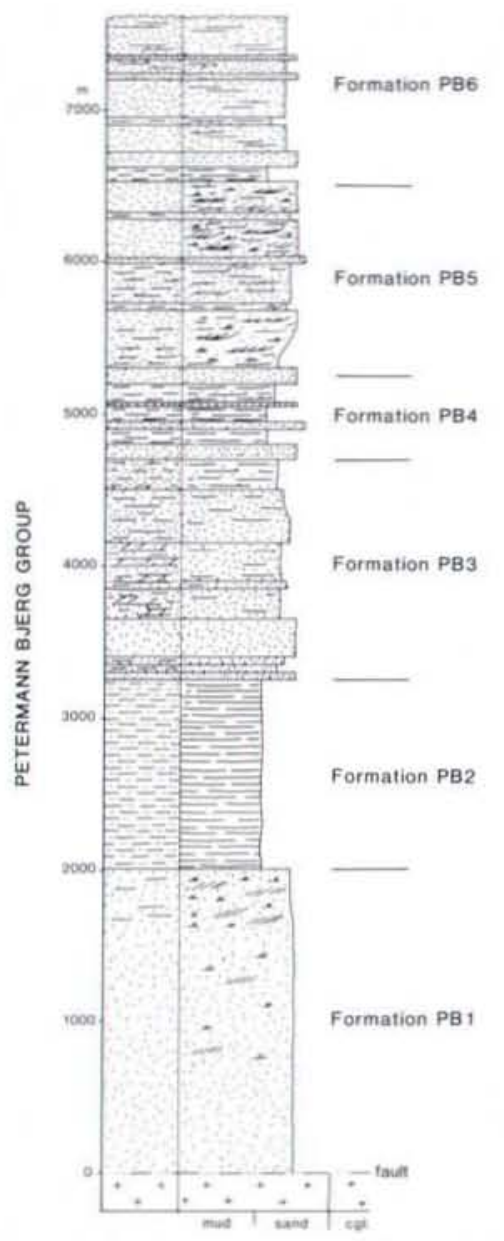

Fig. 15. Generalised sedimentological log of the Petermann Bjerg Group, modified from Wenk \& Haller (1953) and Higgins et al. (1981). For legend see Fig. 5. maps by Koch \& Haller (1971) on Martin Knudsen Nunatakker, in J. L. Mowinckel Land and in westernmost Andrée Land, but these occurrences were not found during GGU reconnaissance in 1975-76 (J. D. Friderichsen, personal communication, 1991).

Dominant lithology. The following summary is based on descriptions by Wenk \& Haller (1953), Haller (1971) and Higgins et al. (1981). The group consists of a succession of white and yellow to purplish weathering quartzose sandstone units, alternating with black, greenish and purplish weathering mudstone units containing varying amounts of sandstone and siltstone. Units range in thickness from a few metres to approximately $2000 \mathrm{~m}$ (Figs 14,15 ). The lower part of the group consists of a $2000 \mathrm{~m}$ thick sandstone unit, which is followed by a more than $1000 \mathrm{~m}$ thick, relatively fine-grained mudstone unit, now transformed into sericite-chlorite phyllites (Fig. 15). This unit is overlain by a $1400 \mathrm{~m}$ thick sandstone package containing scattered dolomite-calcareous lenses and streaks (Fig. 15). The upper part of the group is more variable in lithology, containing rapidly alternating units of sandstone and mudstone. The group has been strongly metamorphosed, particularly in the lower part, and in many areas has been converted into metasediments. Consequently sedimentary structures and original textures are often poorly preserved. Sandstone units, however, locally reveal abundant large-scale cross-bedding and crosslamination, with ripple marks and desiccation cracks commonly preserved on bedding planes. The mudstone units are generally well bedded and dominated by horizontal lamination (Fig. 15).

Depositional environment. There exists at present no interpretation of the depositional environments of the Petermann Bjerg Group. 
Boundaries. The lower contact is placed where the lower sandstone unit of the Petermann Bjerg Group overlies middle Proterozoic metasediments of the central metamorphic complex (Fig. 16). The contact is invariably a décollement zone, traceable throughout the region (Higgins et al., 1981). The upper contact is either faultbounded or erosive.

Fauna and geological age. No fossils have been found within the deposits of the Petermann Bjerg Group, and a search for microfossils in the upper part of the group proved fruitless (G. Vidal in Higgins et al., 1981).

Subdivision. The Petermann Bjerg Group is divided into six informal formations corresponding to the units suggested by Wenk \& Haller (1953) and termed Formations PBI-6 in ascending order (Fig. 13).

\section{Lyell Land Group}

new

History. The Lyell Land Group corresponds to the 'Quartzite Series' as defined by Kulling (1930) and later described in more detail by Teichert (1933), Katz (1952), Eha (1953), Fränkl (1953a, b), Sommer (1957a, b), Haller (1971), Caby \& Bertrand-Sarfati (1988), Sønderholm et al. (1989), Sønderholm \& Tirsgaard (unpublished) and Tirsgaard (in press). It is equivalent to the Argardhsbjerg Formation of Katz (1961) (Fig. 3).

Wenk \& Haller (1953) and Haller (1971) tentatively correlated the upper $2200 \mathrm{~m}$ of the Late Proterozoic sequence found in the Petermann Bjerg region with the lower part of the 'Quartzite Series' (Fig. 3). The validity of this correlation is uncertain as stratigraphic patterns found around Petermann Bjerg are not directly comparable with those of the Lyell Land Group in the central fjord zone. Consequently the deposits of the Petermann Bjerg region are placed in a separate group (see Petermann Bjerg Group above).

In the area north of Ardencaple Fjord, Sommer (1957b) tentatively correlated the so-called 'Bradal Quartzites' with the upper part of the Lyell Land Group and the lower part of the Ymer $\emptyset$ Group. However, this succession was subsequently found to be an inverted section comprising the upper part of the Nathorst Land Group and the lower part of the Lyell Land Group (Fig. 12; Sønderholm et al., 1989).

Lyell Land Group sediments were noted on the map of Koch \& Haller (1971) on the north-eastern tip of Shannon $\left(75^{\circ} \mathrm{N}\right)$, but this occurrence was shown not to belong to the Eleonore Bay Supergroup (A. K. Higgins, personal communication, 1988).

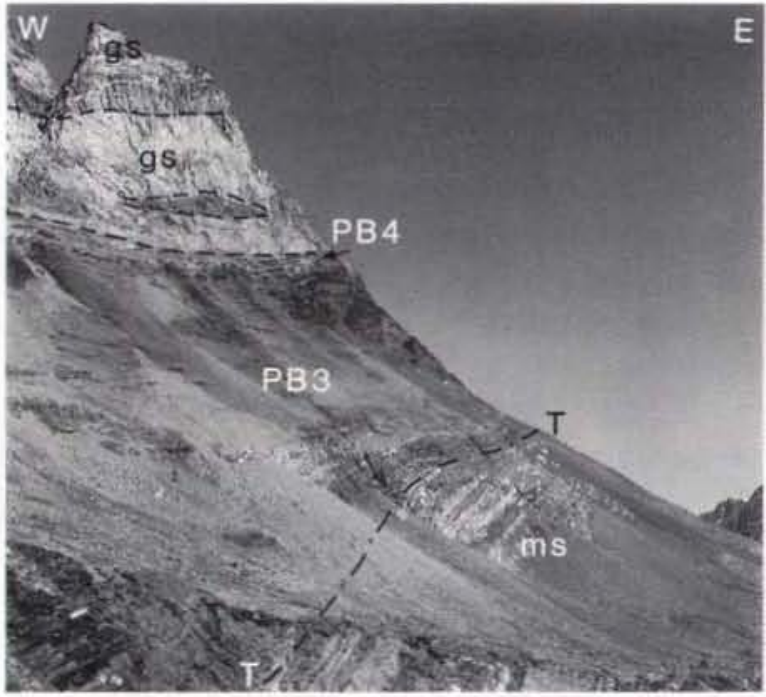

Fig. 16. Lower contact of Petermann Bjerg Group (Formations PB3-4) with older (Middle Proterozoic) metasediments (ms) as exposed in the north wall of Knækdalen, western Frænkel Land. Thick sub-horizontal Caledonian granite sheets (gs) occur in the upper part of the succession. In the lower part of the succession dip increases from very shallow to dips of about $45^{\circ}$, such that the contact with the older metasediments, which are pale due to numerous concordant granitic and pegmatitic veins, appears only slightly unconformable. There are marked shear zones at the contact, and Formation PB3 appears to thin eastwards. Height of cliff c. $1400 \mathrm{~m}$.

Name. After Lyell Land where the group is extensively exposed and well preserved (Fig. 1).

Type area. Lyell Land, from Kap Alfred in the north to Berzelius Bjerg in the south (Figs 1, 17).

Thickness. The group reaches a maximum thickness of $2800 \mathrm{~m}$ in northern Lyell Land around Kap Alfred (Fig. 18). In the rest of the central fjord zone the total thickness varies from $2000 \mathrm{~m}$ to $2500 \mathrm{~m}$ (Katz, 1952; Fränkl, 1953a, b). A similar thickness has been reported from the area between Waltershausen Gletscher and Wordie Gletscher (Haller, 1971; Sønderholm et al., 1989). At least $1500 \mathrm{~m}$ is exposed in the Bredefjord - Ardencaple Fjord area (Sommer, 1957b), and a minimum of $700 \mathrm{~m}$ is found in Canning Land (Sønderholm \& Tirsgaard, unpublished).

Distribution. The group is widely distributed in the area between Wordie Gletscher and central Scoresby Land. The lower and middle parts of the group are also exposed in the Bredefjord - Ardencaple Fjord region (Fig. 12). In northern Canning Land the upper $700 \mathrm{~m}$ of the group is exposed (Fig. 19; Caby, 1972; Sønderholm \& Tirsgaard, 


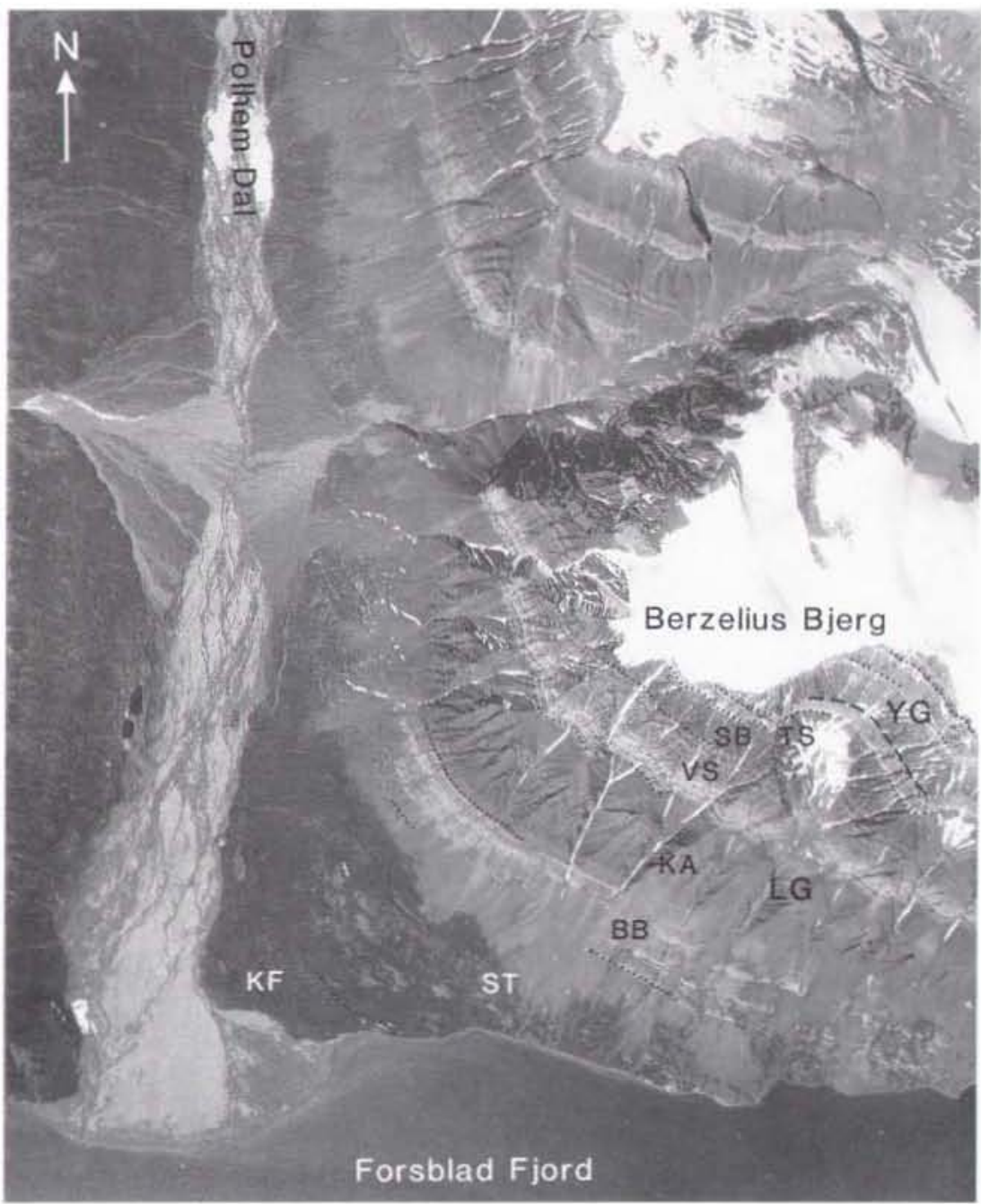

Fig. 17. Aerial photograph of southern Lyell Land around Polheim Dal in southem Lyell Land showing the characteristic outcrop pattern of the Lyell Land Group (LG). KF: Kempe Fjord Formation, ST: Sandertop Formation, BB: Berzelius Bjerg Formation, KA: Kap Alfred Formation. VS: Vibeke So Formation, SB: Skjoldungebra Formation, TS: Teufelsschloss Formation, YG: Ymer $\emptyset$ Group. Aerial photograph $853 \mathrm{H}$, no. 5568. Copyright Kort- og Matrikelstyrelsen. Denmark: reproduced with permission A.87/200.

unpublished). Just north of Älborg Fjord in southern Canning Land a $600 \mathrm{~m}$ thick remnant of sandstone and mudstone is exposed, bounded below by a fault and with an erosional upper contact. Based on lithological comparisons, Caby (1972) tentatively suggested this to correspond to the lower part of the Lyell Land Group.

On Kuhn $\varnothing$ a $650 \mathrm{~m}$ thick isolated succession of sandstone and mudstone of presumably Precambrian age is preserved within a down-faulted block (Fig. 20). This sequence may possibly encompass the lower part of the Lyell Land Group, but it is also possible that the deposits belong to the underlying Nathorst Land Group (A. K. Higgins, personal communication, 1988).

Dominant lithology. The group consists of alternating units of white, brown and purple weathering sandstones and dark green, brown or dark red weathering silty mudstones (Figs 17, 18). Thickness of the units varies be- tween 40 and $600 \mathrm{~m}$. The units have a distinct tabular geometry and can all be traced across most of the outcrop area, forming a lithological pattern which is recognisable from Scoresby Land to Bredefjord. In Canning Land the pattern is partly obscured, but correlation of units is possible (Fig. 19). The group has been subjected to a high degree of metamorphism and is locally strongly deformed, particularly within the lower part; sedimentary structures are commonly poorly preserved. The sandstone units are dominated by well sorted, fine- to mediumgrained quartzose sandstone, with very small amounts of mudstone. Sets of planar and trough cross-bedding. which never exceed $1 \mathrm{~m}$ in height, are dominant, with parallel lamination and ripple cross-lamination being of subordinate importance. Desiccation cracks are common within most of the sandstone units. The mudstone units are dominated by parallel laminated silty mudstone, often showing graded rhythmites a few millimetres to centi- 


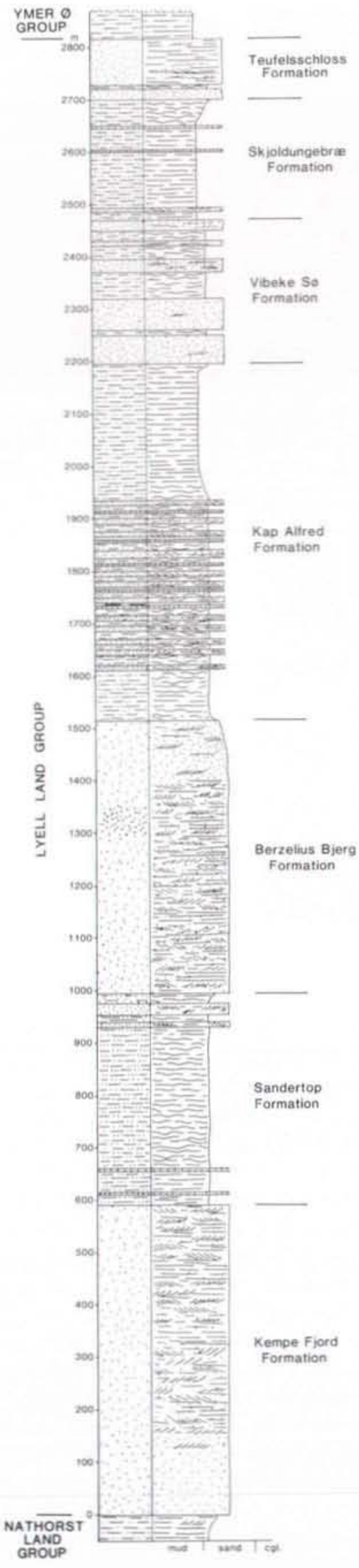

metres thick, which are interbedded with beds of sandstone $2 \mathrm{~cm}$ to $2 \mathrm{~m}$ thick. Syneresis cracks are commonly found on bedding planes.

Sandstone units are thickest in northern Lyell Land and thin only slightly towards the north. In contrast they thin rapidly towards southern Lyell Land and Scoresby Land, with a concomitant increase in thickness of the mudstone units. Sandstone units are markedly thinner in Canning Land (Fig. 19).

Depositional environment. The Lyell Land Group mainly represents siliciclastic marine shelf environments, spanning from the outer to inner shelf, including shoreface deposits. Sediments of the inner shelf areas show influence of both tidal currents and storms, while storm deposition dominated outer shelf areas (Sønderholm \& Tirsgaard, unpublished).

Fauna and geological age. Thirty-three samples from the group have been processed for acritarchs, but apart from one sample acritarchs are scarce and poorly preserved. Large, black sphaeromorphs could possibly be ascribed to Chuaria circularis. One sample from the upper part of the group has yielded specimens of Kildinella $\mathrm{cf}$. $K$. hyperboreica, Protosphaeridium cf. P. patelliforme, Stictosphaeridium sp. and Synsphaeridium sp. together with possible $C$. circularis. The presence of Kildinella $\mathrm{cf}$. $K$. hyperboreica suggests a Sturtian age (Late Riphean of Vidal. 1979) for the group, as this species is restricted to the Sturtian and Vendian (Vidal, 1976, 1979).

Boundaries. The boundary between the Nathorst Land Group and the Lyell Land Group is described above. The upper boundary of the Lyell Land Group is placed where white sandstones or dark brown heterolithic sandstone and mudstone deposits are sharply overlain by dark red or purple fine- grained mudstones of the Ymer $\emptyset$ Group (Figs 21, 22). This contact is widely and well exposed from Canning Land in the south, throughout the central fjord zone and as far as Wordie Gletscher in the north.

Subdivisions. The group is divided into seven formations, corresponding to the main sandstone and mudstone units. These include from base to top the Kempe Fjord, Sandertop, Berzelius Bjerg, Kap Alfred, Vibeke Sø, Skjoldungebre and the Teufelsschloss Formations. The Kempe Fjord and Sandertop Formations correspond to bedgroup 1' while the remaining upper five formations corre-

Fig. 18. Generalised sedimentological log of the Lyell Land Group measured at Kap Alfred, northern Lyell Land. For legend see Fig. 5. 


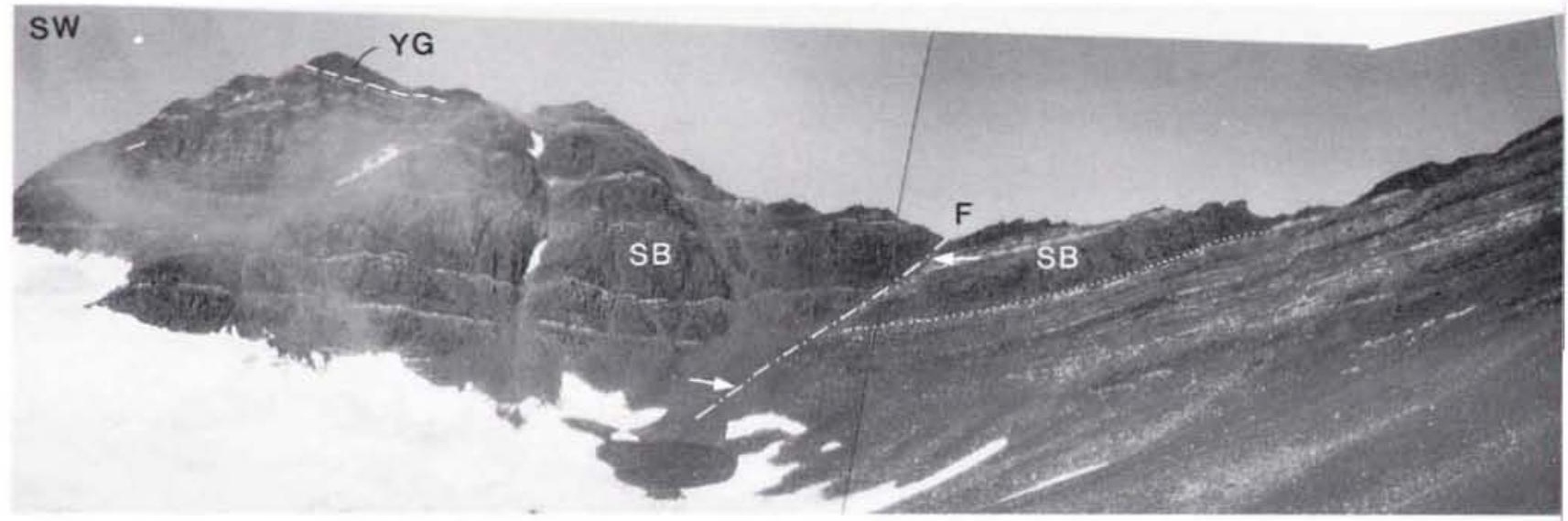

Fig. 19. Lyell Land Group as exposed at Ärhus Bugt in northern Canning Land. The contact between the Nathorst Land Group (NG) and Lyell Land Group is a thrust (T-T), and minor faulting (F) occurs in the section (arrows indicate points of correlation across the fault). Height of cliffs in left part of picture is c. $400 \mathrm{~m}$. VS: Vibeke Sø Formation, SB: Skjoldungebra Formation, YG: Ymer $\emptyset$

spond to 'bed-groups 2-6' (Fig. 18; Sønderholm \& Tirsgaard, unpublished).

\section{Ymer Ø Group}

new

History. The strongly variegated rocks of the Ymer $\varnothing$ Group belong to the 'classical' part of the Eleonore Bay Supergroup; it was, in part, rocks of this unit which were described by Toula (1874) and Lenz (1874). The group corresponds to the 'Multicoloured Series' of the Upper Eleonore Bay Group (cf. Haller, 1971; Henriksen \& Higgins, 1976) and to the Brogetdal Formation of Katz
(1961) (Fig. 3). More detailed descriptions of this unit have been given by Katz (1952), Eha (1953), Fränkl (1953a, b), Haller (1953), Sommer (1957a), Caby (1972), Caby \& Bertrand-Sarfati (1988), Sønderholm et al. (1989), Sønderholm \& Tirsgaard (1990) and Sønderholm \& Tirsgaard (unpublished).

Sommer (1957b) correlated parts of his 'Brædal Quartzites' in the Ardencaple Fjord region with the Ymer $\emptyset$ Group, but this succession has been shown to be an inverted sequence of the Nathorst Land and Lyell Land Groups (Fig. 12; Sønderholm et al., 1989).

Name. After Ymer $\emptyset$ where the group is extensively and well exposed (Fig. 1).

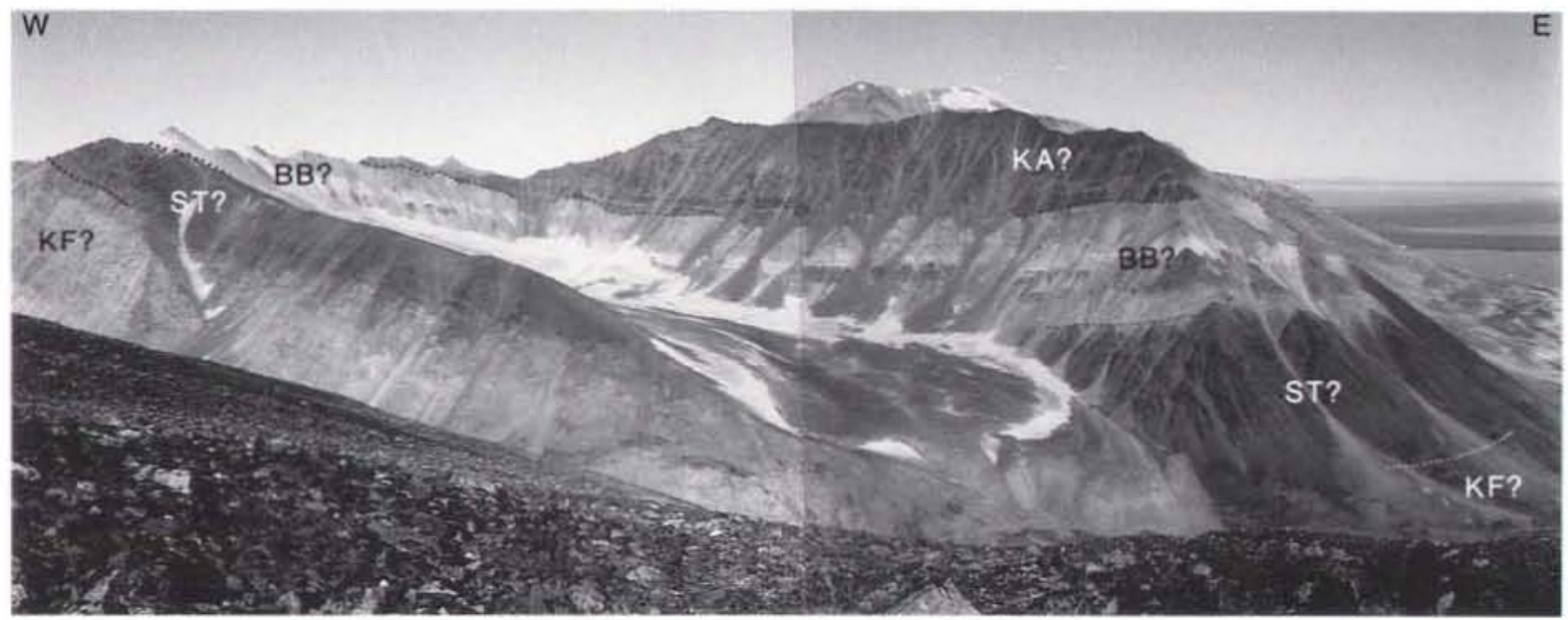

Fig. 20. Possible Lyell Land Group deposits on north-western Kuhn $\emptyset$ at Bastian Bugt. Thickness of section is c. $650 \mathrm{~m}$ and possibly shows Kempe Fjord Formation (KF), Sandertop Formation (ST), Berzelius Bjerg Formation (BB) and Kap Alfred Formation (KA). 


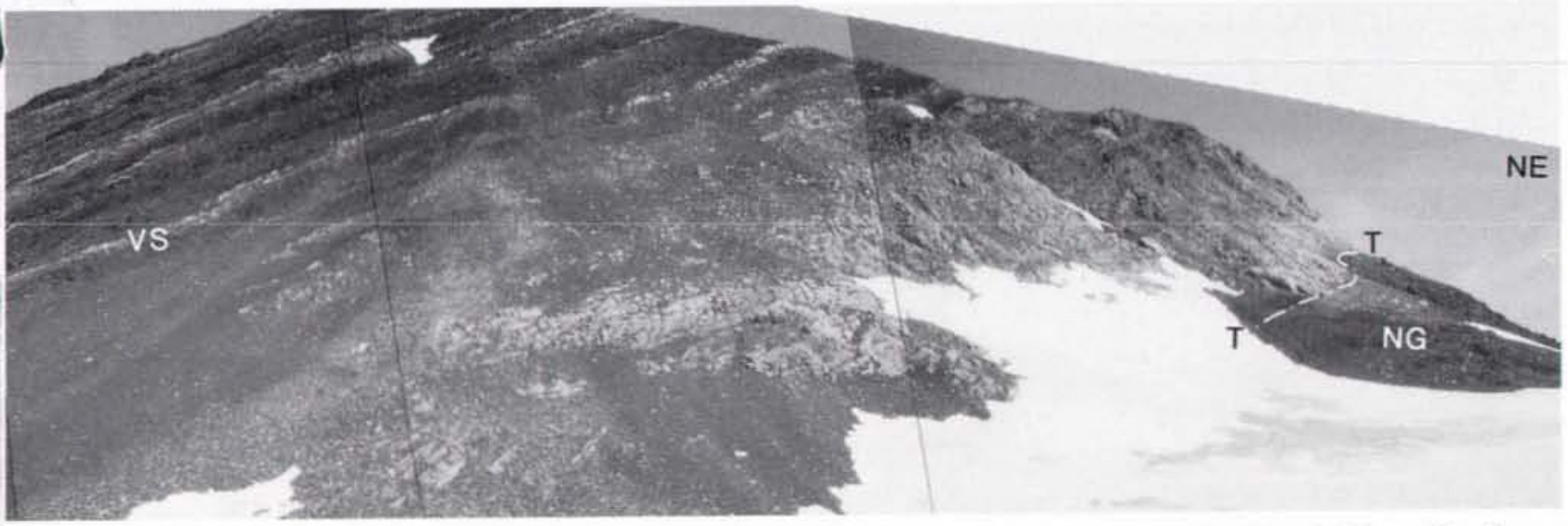

Group. The Teufelsschloss Formation which forms the top of the Lyell Land Group in areas north of Segelsallskapet Fjord is not present in Canning Land.

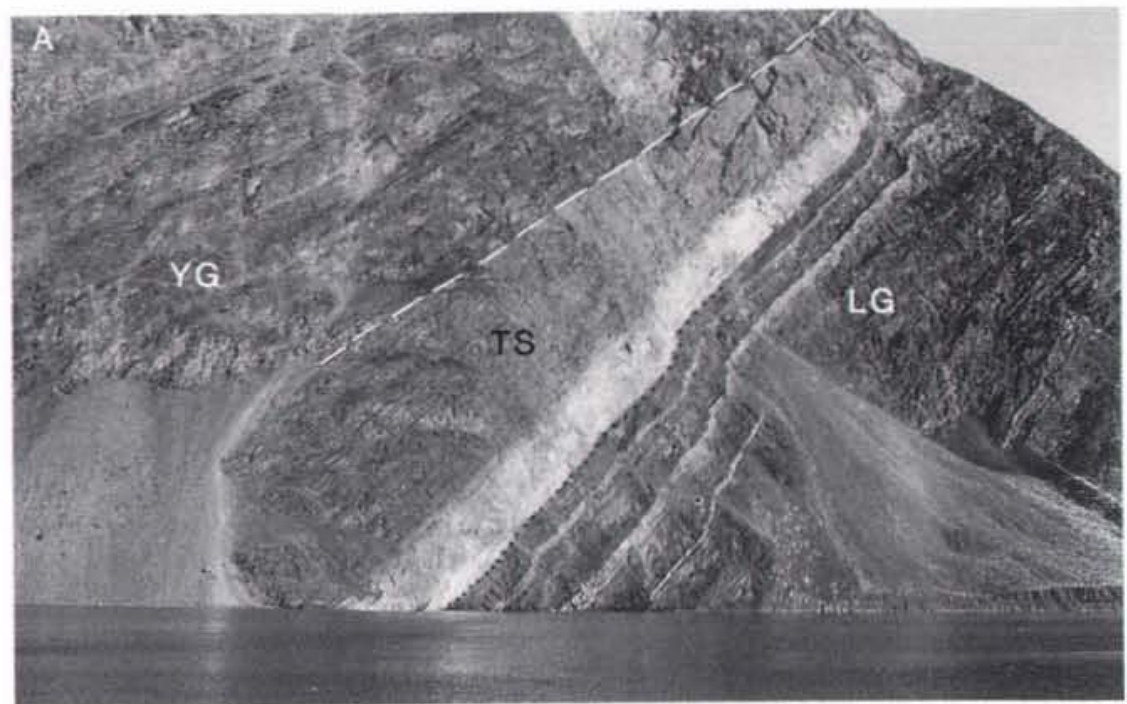

Fig. 21. Boundary (dashed) between the Lyell Land Group (LG) and the Ymer $\emptyset$ Group (YG) as exposed on southern Ymer $\emptyset$ (A) and along the cliffs of Berzelius Bjerg. southern Lyell Land (B). Note that the darker weathering top of the Teufelsschloss Formation (TS) on Ymer $\emptyset$ is not present in the southern region around Berzelius Bjerg. Thickness of Teufelsschloss Formation $130 \mathrm{~m}$ on Ymer $\emptyset, 80 \mathrm{~m}$ at Berzelius Bjerg.

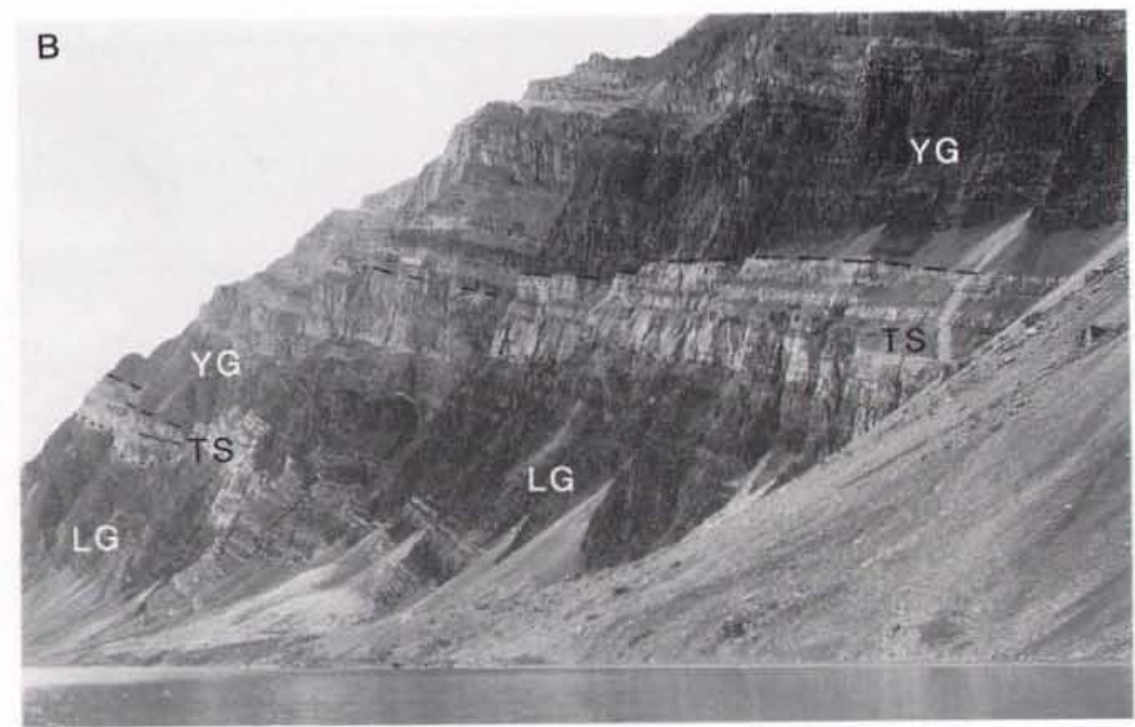




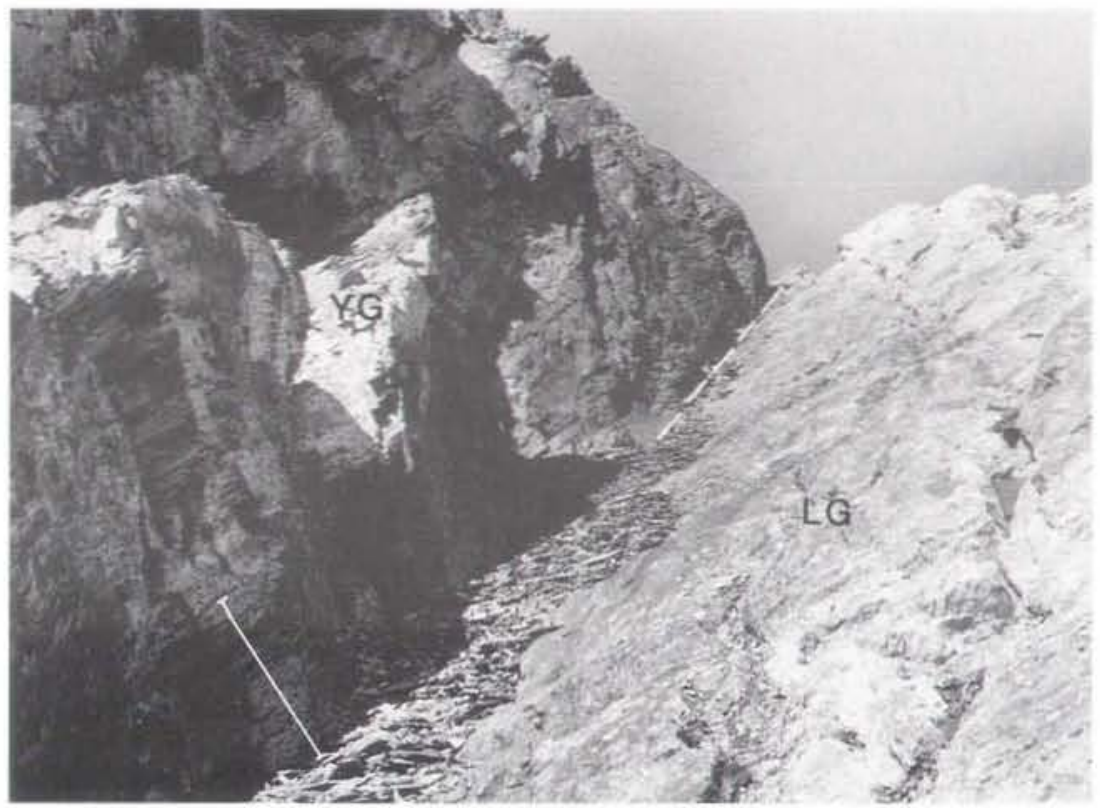

Fig. 22. Detail of sharp contact between Lyell Land Group (LG) and Ymer $\emptyset$ Group (YG), scale-bar shows $1 \mathrm{~m}$.

Type area. Along the southern coast of Ymer $\emptyset$, where all formations of the group are well exposed in steeply dipping beds (Fig. 23).

Thickness. The maximum thickness of the group is on Ymer $\emptyset$ where it reaches $1200-1300 \mathrm{~m}$ (Fig. 24; Eha, 1953: Sonderholm \& Tirsgaard, 1990). In the rest of the outcrop area, to the north and south, the group attains thicknesses of 900-1000 m (Katz, 1952; Fränkl, 1953a, b: Sommer, 1957a). In Canning Land a minimum thickness of $900 \mathrm{~m}$ has been reported (Sønderholm \& Tirsgaard, unpublished).

Distribution. The Ymer $\emptyset$ Group is widely exposed from Canning Land in the south, throughout the central fjord zone to Wordie Gletscher in the north. On southern Hochstetter Forland, even further to the north, some isolated, small and incomplete outcrops also occur (Fig. 1); they
Fig. 23. Type locality of the Ymer $\emptyset$ Group on the south coast of Ymer $\emptyset$ along Antarctic Sund. Height of eastern mountain is c. $1250 \mathrm{~m}$. The formations of the Ymer $\emptyset$ Group are from base to top Kap Peterséns Formation (KP. with Skyggedal Member. SD, on top). Antarctic Sund Formation (AS). Tágefjeld Formation (TF), Rytterknagten Formation (RK), Skildvagten Formation (SK) and Elisabeth Bjerg Formation (EB). To the east the Lyell Land Group (LG) with Skjoldungebra (SB) and Teufelsschloss (TS) Formations is well exposed. Formations ALI-5 of the Andrée Land Group occur to the west.

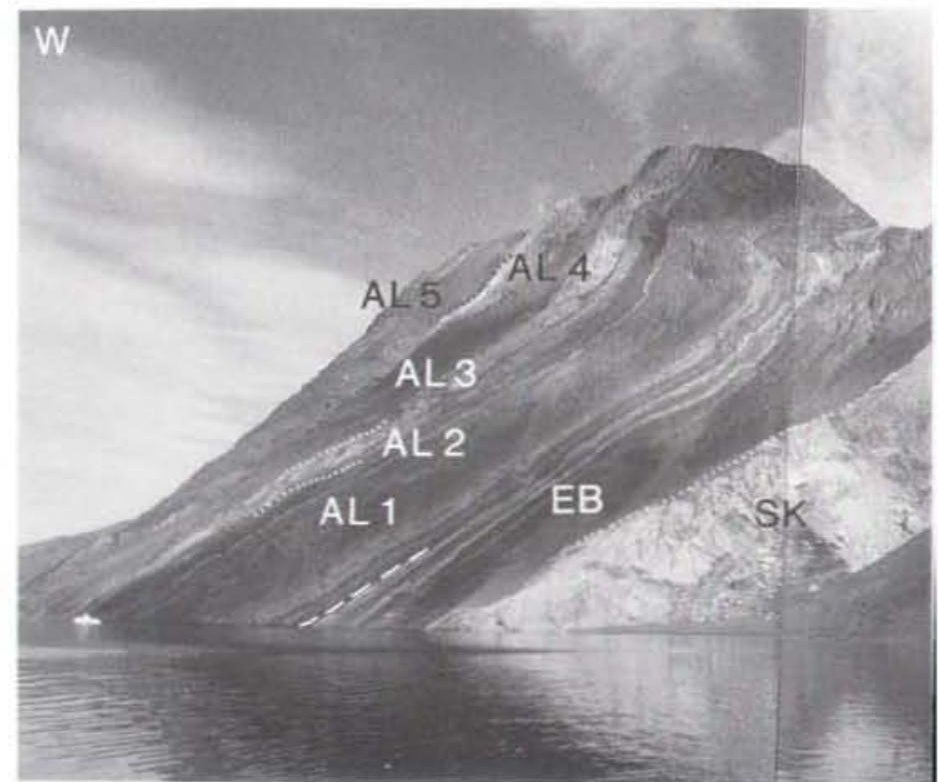


were previously described as forming part of the Andrée Land Group ('Limestone-Dolomite Series' of Sommer, 1957b) but are now recognised as part of the Ymer $\emptyset$ Group (Sønderholm et al.. 1989).

Dominant lithology. The strongly variegated rocks of the Ymer $\emptyset$ Group comprise six $60-290 \mathrm{~m}$ thick formations consisting of dark grey, rusty brown and red siliciclastic mudstone and sandstone, dark grey to black limestone, and white, yellow and brownish red dolomite (Fig. 24). The lowermost formation mainly consists of dark red to brownish siliciclastic, partially calcareous, horizontally laminated to lenticular bedded sandy mudstone, with local large-scale channellised slump structures. The remaining part of the group, apart from the uppermost formation, consists of alternating dark limestone and variously coloured dolomite. The dark limestone comprises thin to medium wavy-bedded, massive and algally laminated limestone with abundant soft sediment structures. Chert and resedimented and slumped horizons are common. Current-induced structures are locally present at certain levels within the dark limestone formations. The dolomite formations comprise white, mainly algal biostromes and primarily brownish red and yellow, mediumbedded, parallel laminated silty dololutite. The latter contains conspicuous speckled horizons with green, red and white calcite nodules and contorted bands of white calcite. In the northern part of the fjord region, complex algal mound structures up to $80 \mathrm{~m}$ thick and $250 \mathrm{~m}$ wide and large-scale slump scars are also present within this unit. The uppermost formation of the group is character- ised by a distinctive alternation of dark siliciclastic units and bright pale yellow to orange dolomite units. The siliciclastic deposits consist of stacked coarsening upward sequences ranging from finely laminated mudstone to thick fine- to coarse-grained sandstone bodies with a lenticular geometry. The dolomite units are dominated by stromatolitic biostromes and bioherms.

Depositional environment. The Ymer $\emptyset$ Group represents a wide range of depositional environments spanning from siliciclastic basinal and slope deposits over carbonate slope, outer-shelf and shoal deposits to inner-shelf siliciclastic and carbonate deposits. A widespread interlude of evaporitic sulphate deposition has also been recognised (Sønderholm et al., 1989; Sønderholm \& Tirsgaard, unpublished). The deposits represent two significant phases of shelf progradation induced by major transgressive events at the base and in the middle of the group (Sønderholm \& Tirsgaard, unpublished).

Boundaries. The lower boundary with the Lyell Land Group is described above. The boundary between the Ymer Ø Group and the overlying Andrée Land Group is sharp and generally placed at the abrupt change from yellow and red, recessive weathering interbedded dolomite and siliciclastic mudstone to cliff-forming, yellowweathering dolomite which rapidly grades into dark greyweathering limestone (Figs 25, 26).

Katz (1952) placed the boundary slightly higher, as he also included two limestone units (the "Grey Band" or 'Graues Band' and the 'Stripey Yellow Band' or 'Gelb-

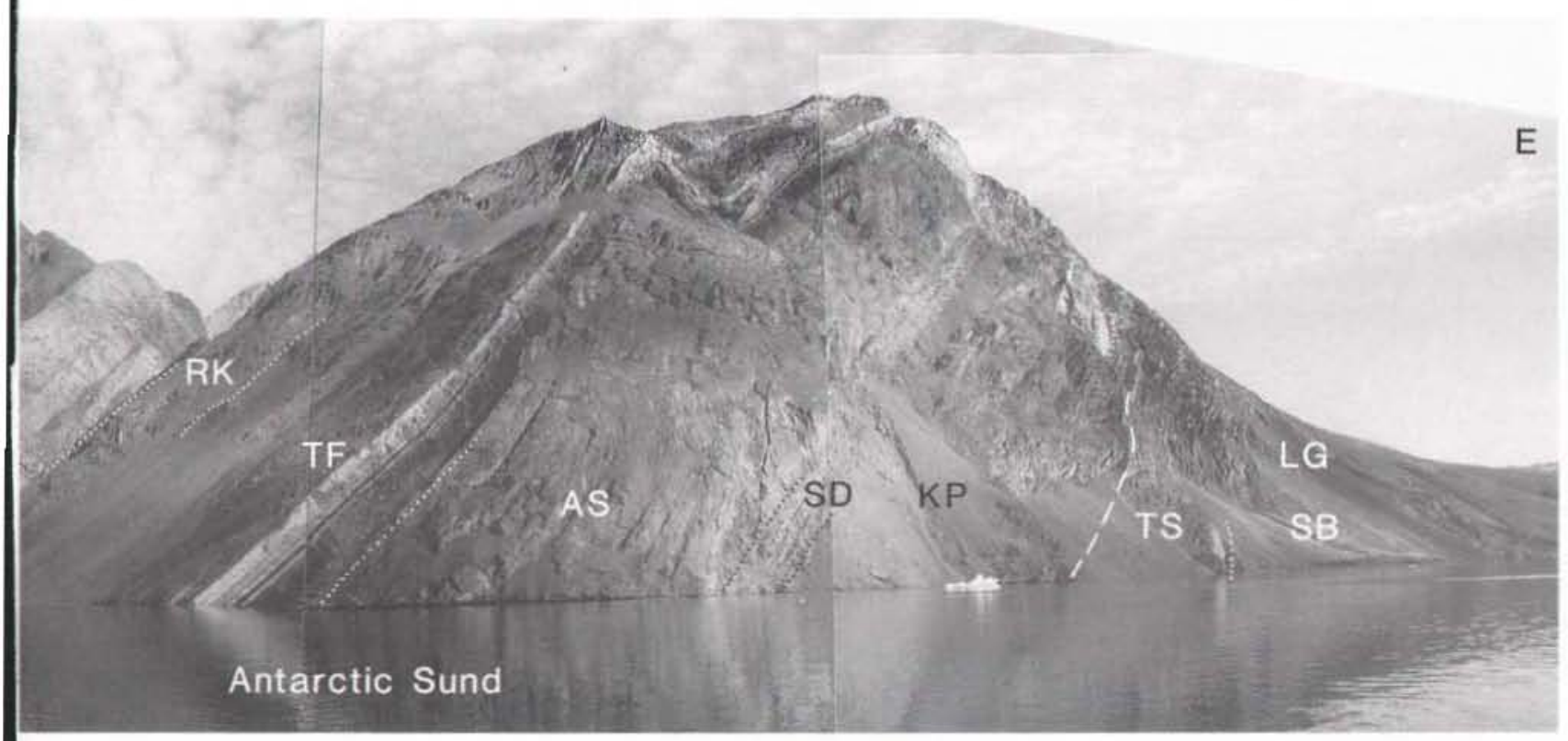




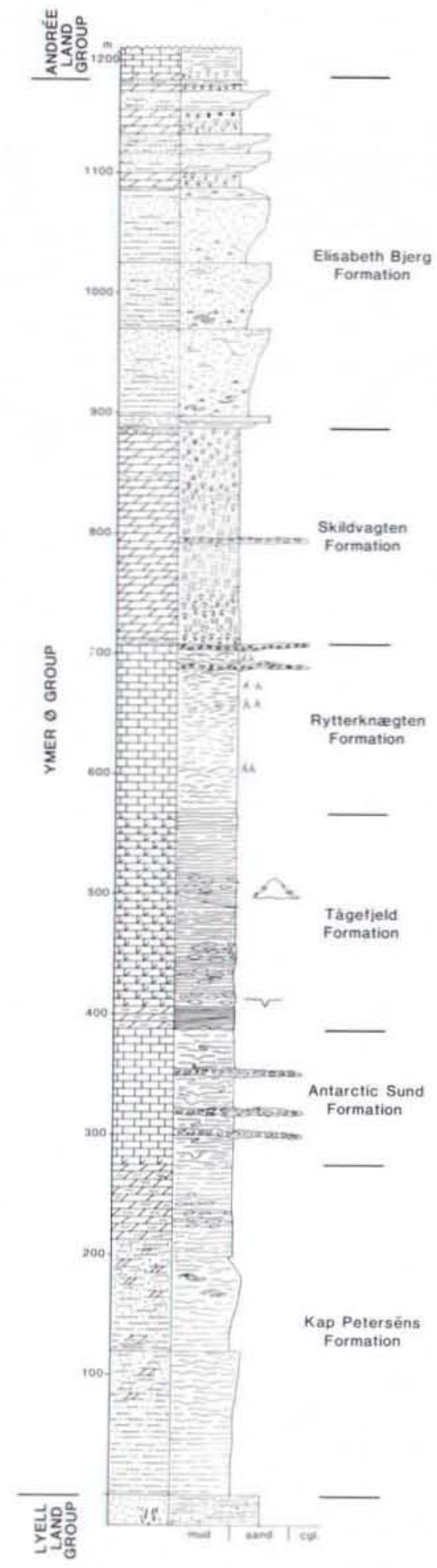

Fig. 24. Generalised composite sedimentological log of the Ymer $\emptyset$ Group. For legend see Fig. 5. gestreiftes Band') in the top part of his equivalent to the Ymer $\emptyset$ Group. These two units were assigned to 'bedgroups 14a and 14b' (now lower part of Formation AL1, Andrée Land Group) by Sønderholm \& Tirsgaard (1990).

Fauna and geological age. Fifteen samples from the group have been processed for microfossils, but only two yielded identifiable material. Five taxa were recovered: Chuaria circularis, Pterospermopsimorpha? cf. P. densicoronata, Stictosphaeridium sp., Synsphaeridium sp. and Trachysphaeridium levis. However, this assemblage only indicates a general Late Proterozoic age (Vidal, 1976, 1979).

Taxonomic studies of stromatolites from the Ymer $\emptyset$ Group in Canning Land have revealed a diverse assemblage, and four new taxa have been described (BertrandSarfati \& Caby, 1976).

Subdivisions. The Ymer $\emptyset$ Group is divided into six formations which, from bottom to top, are: the Kap Peterséns, Antarctic Sund, Tãgefjeld, Rytterknæegten, Skildvagten and Elisabeth Bjerg Formations (Fig. 24). The Kap Peterséns Formation corresponds to "bed-groups 7 and 8' of the 'Multicoloured Series' while the upper five formations correspond to 'bed-groups 9-13' (Sønderholm \& Tirsgaard, unpublished).

\section{Andrée Land Group \\ new}

History. The Andrée Land Group corresponds to the 'Limestone-Dolomite Series' as initially defined by Teichert (1933), and to the Nøkkefossen Formation of Katz (1961) (Fig. 3). More detailed lithological descriptions are given by Schaub (1950), Poulsen \& WienbergRasmussen (1951), Katz (1952), Eha (1953), Fränkl (1953a, b), Haller (1953), Sommer (1957a), Caby (1972), Caby \& Bertrand-Sarfati (1988), Herrington \& Fairchild (1989), Swett \& Knoll (1989), Hambrey et al. (1989), Sønderholm et al. (1989) and Sønderholm \& Tirsgaard (1990).

Sommer (1957b) correlated the outcrops on southern Hochstetter Forland with the Andrée Land Group. However, these deposits have been shown to belong to parts of the Ymer $\emptyset$ Group (Sønderholm et al., 1989).

Name. From Andrée Land.

Type area. The eastern tip of Andrée Land where the group is fully developed, easily accessible and well described (Figs 1, 2). 
Fig. 25. Boundary between Ymer $\emptyset$ Group (YG) and Andrée Land Group (AG, Formations AL1-3) at the type locality at Antaretic Sund. EB: Elisabeth Bjerg Formation (300 $\mathrm{m}$ thick). SK: Skildvagten Formation.

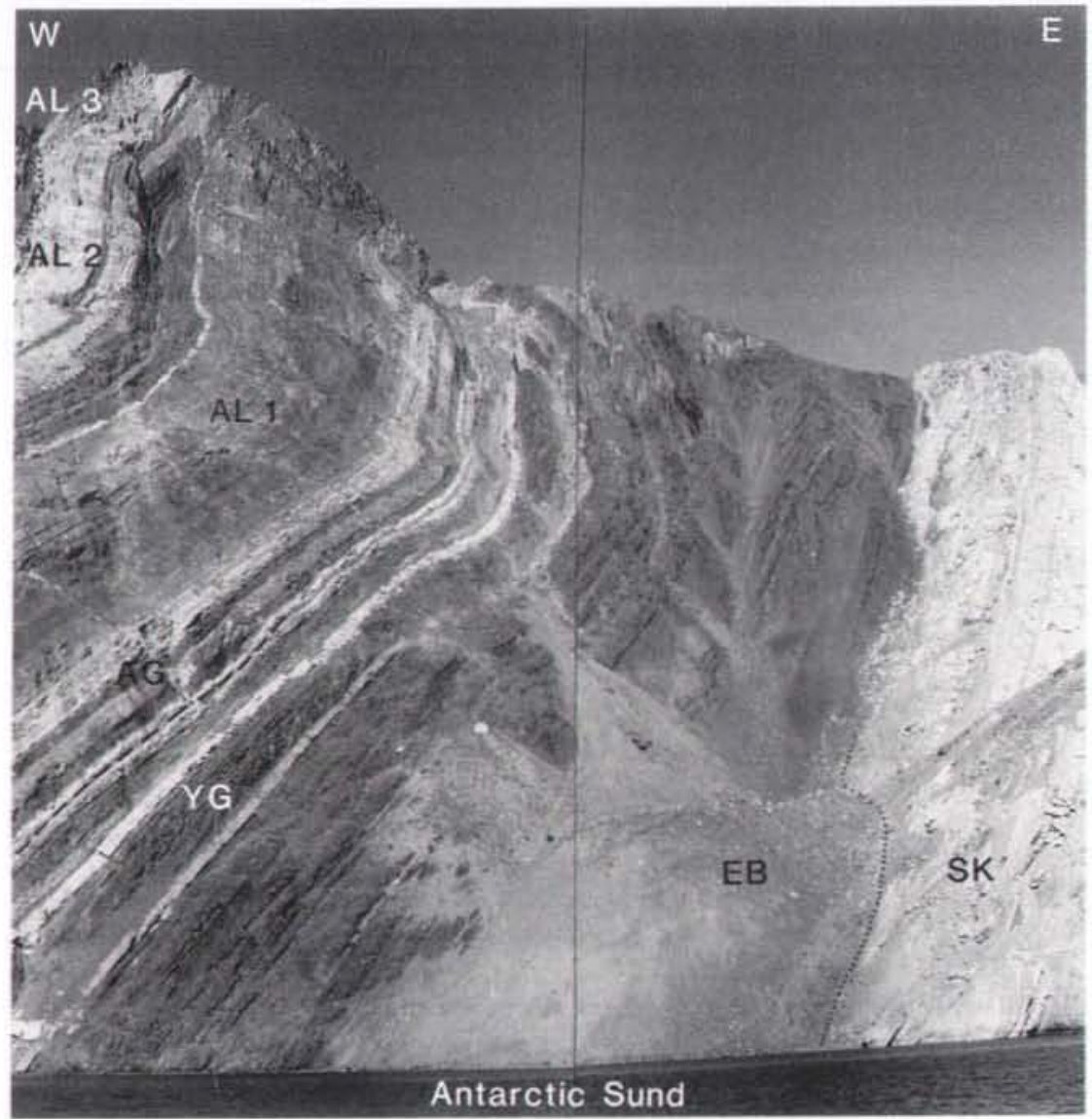

Thickness. In the central fjord zone, thicknesses between 900 and $1500 \mathrm{~m}$ have been reported (Fig. 27; Katz, 1952; Fränkl, 1953a, b; Eha, 1953; Sommer, 1957a; Herrington \& Fairchild, 1989). A minimum thickness of $900 \mathrm{~m}$ has been reported from Canning Land (Caby, 1972). Thicknesses in excess of $1500 \mathrm{~m}$ have been reported from Steno Land and Payer Land (Haller, 1971; Sønderholm et al., 1989).

Distribution. The group crops out extensively between northern Scoresby Land and Wordie Gletscher. Parts of the group are also found in Canning Land to the south and Payer Land to the north (Fig. 1; Teichert, 1933; Hambrey et al., 1989). The occurrences of the group on C. H. Ostenfeld Nunatak reported by Teichert (1933), Haller (1971), Koch \& Haller (1971) and Frykman (1979) have now been recognised to be both Tillite Group sediments and Lower Cambrian carbonates (Hambrey et al., 1989). The outcrop on southern Hochstetter Forland reported by Sommer (1957b) is now placed within the Ymer Ø Group (Sønderholm et al., 1989).
Dominant lithology. The following description of the Andrée Land Group is mainly based on summaries by Haller (1971) and Henriksen \& Higgins (1976) with some additional data from Herrington \& Fairchild (1989), Sønderholm et al. (1989), Swett \& Knoll (1989) and Sønderholm \& Tirsgaard (1990). The main part of the group consists of $80-400 \mathrm{~m}$ thick units of generally dark grey to black, thin, wavy-bedded, sometimes shaly limestone, with two intercalations of $50-80 \mathrm{~m}$ thick units of white or bright orange-red massive, stromatolitic or pisolitic dolomite (Fig. 23) locally showing strong intraformational brecciation (Fig. 27). In the lower part of the group, the dark limestones contain abundant intraformational, strongly erosive, matrix supported conglomerates $10-80 \mathrm{~cm}$ thick, while pisolitic limestones or dolomites, often forming tabular units, are common in the middle part of the group. The uppermost part of the group comprises a $160-220 \mathrm{~m}$ thick unit of variegated bituminous dolomitic shale, which locally is slumped and disrupted to form breccias, and a unit of dark calcareous shale and dolomitic limestone up to $80 \mathrm{~m}$ thick (Fig. 27). The 


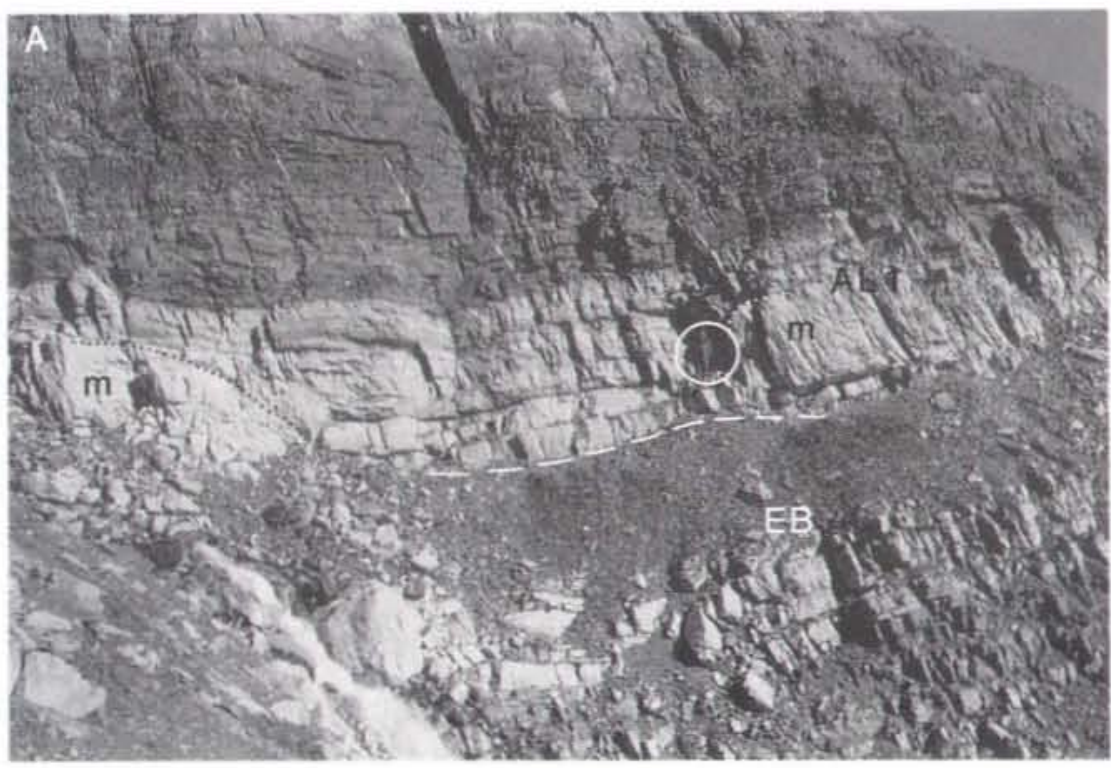

Fig. 26. Detail of boundary between Ymer $\emptyset$ Group (EB) and Andrée Land Group (ALI), encircled person for scale. A. Central Ymer $\emptyset$ where mudstones forming top of Elisabeth Bjerg Formation (EB) are overlain by moundy (m) stromatolitic dolomite. B. Central Strindberg Land where Caledonian thrusting has occurred within the boundary mudstones (note the deformed bedding and rotated blocks beside the person).

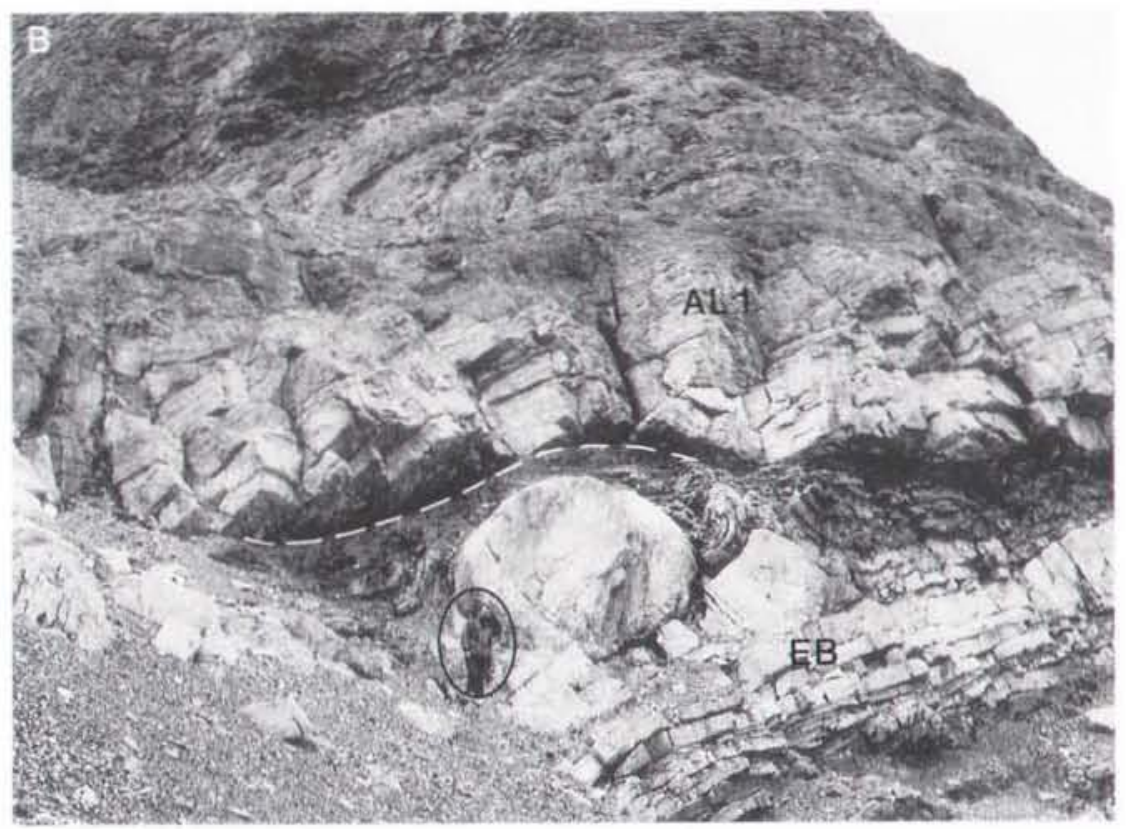

lithologies and thicknesses of the formations within the group, especially the dolomitic units, are more changeable than in the underlying Lyell Land and Ymer $\emptyset$ Groups.

Depositional environment. The Andrée Land Group represents carbonate platform environments ranging from slope to supratidal, locally evaporitic settings (Herrington \& Fairchild, 1989; Sønderholm \& Tirsgaard, 1990). In the lowermost part of the group low-energy subtidal set tings, periodically influenced by storms, dominate. Most of the remaining part of the group shows evidence of high-energy subtidal to coastal deposition. Local evaporitic environments are suggested by the presence of possible dissolution collapse breccias. The uppermost part of the group accumulated in a slope environment, as represented by periplatform ooze, turbidites and slump deposits. These deposits are locally overlain by sediments of shallow subtidal origin. 
Boundaries. The boundary between the Andrée Land Group and the underlying Ymer $\emptyset$ Group is described above. The upper boundary conforms with the top of the Eleonore Bay Supergroup, also described above.

Fauna and geological age. A total of 43 processed samples from the Andrée Land Group have produced abundant microfossil material. Twenty-four samples yielded a total of 15 taxa: Chuaria circularis, Kildinella hyperboreica, $K$. sinica, $K$. vesljanica, Protosphaeridium laccatum, Pterospermopsimorpha? densicoronata, cf. Stictosphaeridium sp., S. verrucatum, Synsphaeridium sp., Thuruchanica sp., Trachysphaeridium sp., T. laminaritum, $T$. laufeldi, T. levis, and T. timofeevi (Vidal, 1976, 1979). This assemblage is interpreted as Sturtian in age (Late Riphean of Vidal, 1979).

In addition, different cyanobacterial assemblages (microfossil assemblages) have been described from the Andrée Land Group (Knoll et al., 1986a; Green et al., 1987, 1988, 1989), and taxonomic studies of stromatolites have been carried out in Canning Land (Bertrand- Sarfati \& Caby, 1976).

Subdivisions. The Andrée Land Group is divided into seven informal formations corresponding to 'bed-groups 14-20' of the 'Limestone-Dolomite Series'. The formations of the Andrée Land Group from base to top are termed Formations AL1-AL7 (Fig. 27). At present it seems premature to erect a formal lithostratigraphic subdivision as problems concerning the actual stratigraphic position and distribution, as well as the nature of the major dolomitised units (Formations AL2 and AL4), have yet to be unravelled.

Fig. 27. Generalised composite sedimentological log of Andrée Land Group, modified from Katz (1952), Fränkl (1953a) and Herrington \& Fairchild (1989). For legend see Fig. 5.

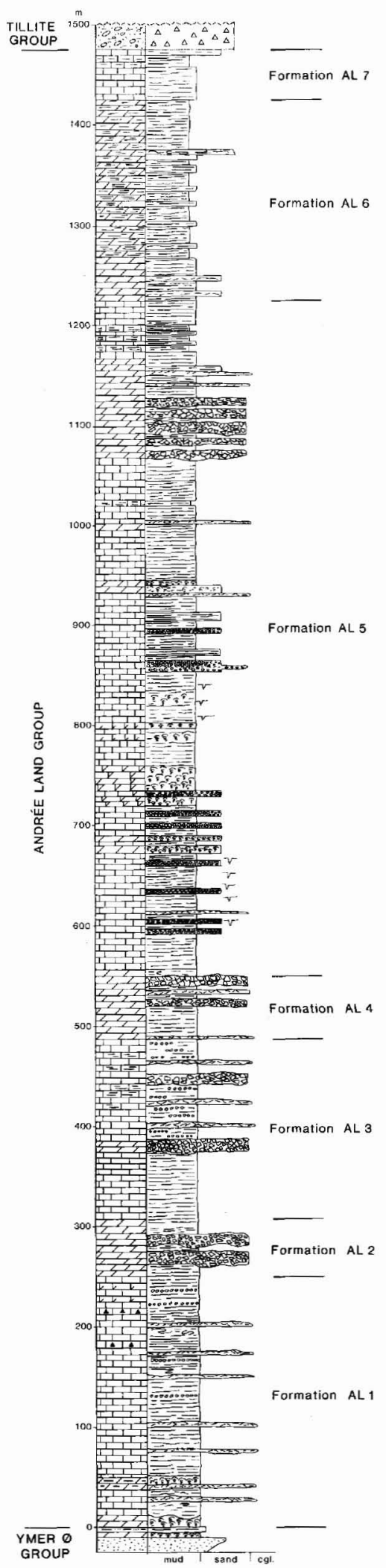




\section{Correlation with other areas in the North Atlantic region}

In the North Atlantic region extensive basin development was initiated 800-900 Ma ago and continued to evolve until Ordovician time. Tectonic activity accompanying basin formation was related to the disintegration of the Late Precambrian supercontinent (Piper, 1982) and the subsequent creation of the Iapetus Ocean (e.g. Harland \& Gayer, 1972; Winchester, 1988). Evidence of Late Proterozoic basin formation comes from thick successions of siliciclastic and carbonate sediments preserved within Svalbard, northern and southern Scandinavia, the British Isles and North and East Greenland (Figs 28, 29). These deposits are often assumed to have been laid down along the margins of the Iapetus Ocean (e.g. Harland \& Gayer, 1972), or within ensialic basins formed during initial crustal extension prior to the actual formation of the Iapetus Ocean (e.g. Winchester, 1988; Harland et al., 1992).

Glacigenic deposits of Vendian (Varanger) age overlie most of these Late Proterozoic successions (e.g. the Tillite Group in East Greenland) and form important marker beds, constraining the upper age of the underlying Late Proterozoic deposits (Fig. 29; Hambrey, 1988; 1989). Precise dating of the often very thick Late Proterozoic sediments is, however, poor due to a paucity of isotopic age determinations and low age resolution of preserved microfossil assemblages. Combined with high degrees of metamorphic overprint and deformation this makes more detailed comparisons between the areas difficult.

The more extensive Late Proterozoic deposits, commonly assumed to have formed within the same major basin and concurrent with the deposits of the Eleonore Bay Supergroup, are briefly discussed below and compared with the succession in central East Greenland.

The succession which shows the greatest lithological similarity to the Eleonore Bay Supergroup is part of the Hecla Hoek sequence in eastern Svalbard (Figs 28, 29). These two successions show much the same sedimentary evolution, lack major stratigraphical breaks and attain approximately equal thicknesses (Harland \& Gayer, 1972; Harland, 1985; Harland et al., 1992). The glacial deposits in the two areas are also very similar (Hambrey, 1989). The close relationship of the two Late Proterozoic successions is further suggested by chemostratigraphic analysis (Knoll et al., 1986b) and microfossil assemblages (Vidal, 1985; Green et al., 1989; Swett \& Knoll, 1989). Consequently it seems reasonable to consider the two successions to have formed within a once contiguous basin and that eastern Svalbard was positioned very close to central East Greenland during the Late Proterozoic (Hambrey, 1989).

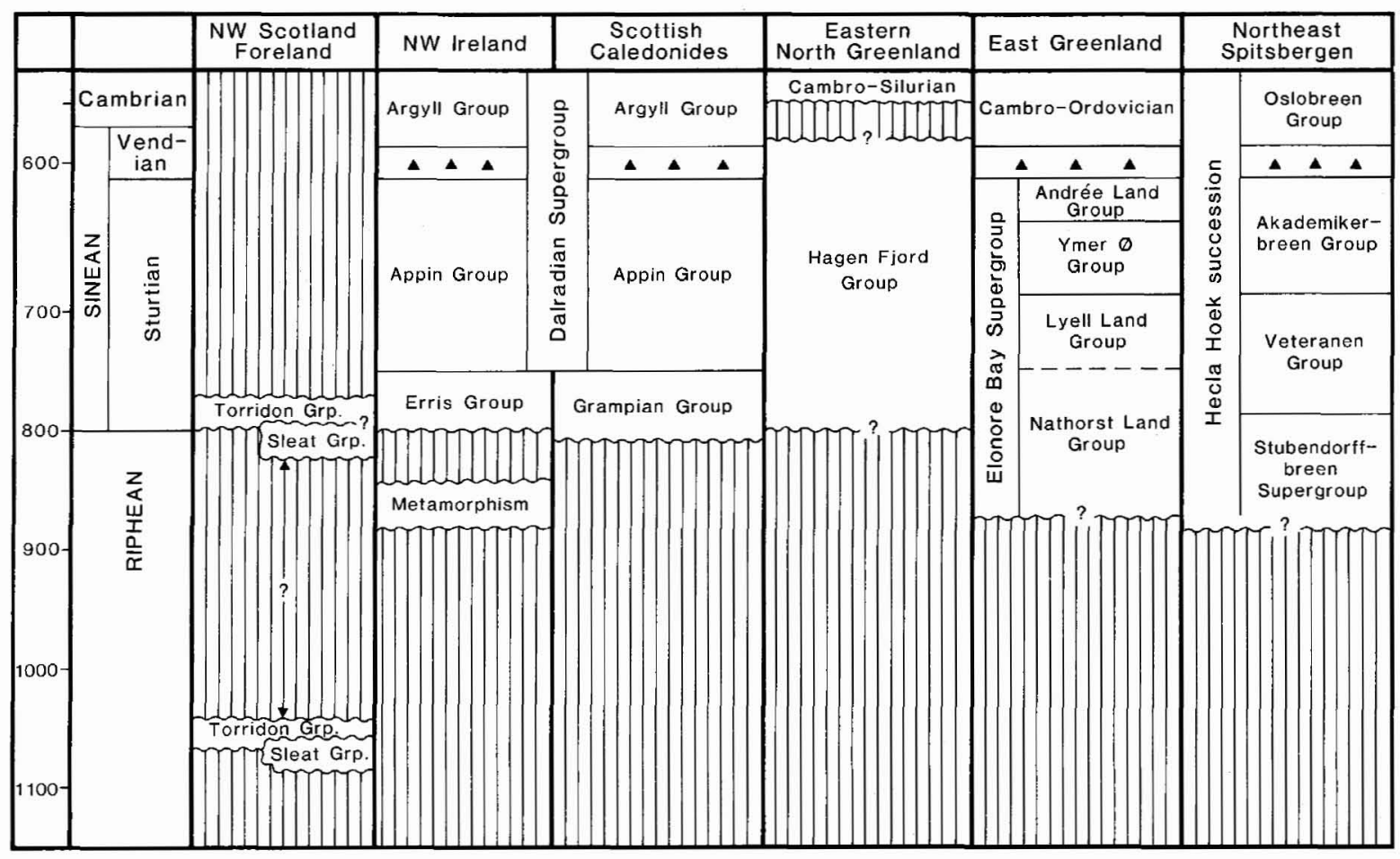


Fig. 28. Outcrops of Late Proterozoic basins in the North Atlantic region and adjoining areas. EB: Eleonore Bay Supergroup; HF: Hagen Fjord Group; HH: Hecla Hoek succession; RP: Russian Platform; SP: 'sparagmite' deposits; TGA: Torridonian succession, Grampian, Erris and Appin Groups; VTB: Vads $\varnothing$, Tanafjord and Barents Sea Groups. From Winchester (1988).

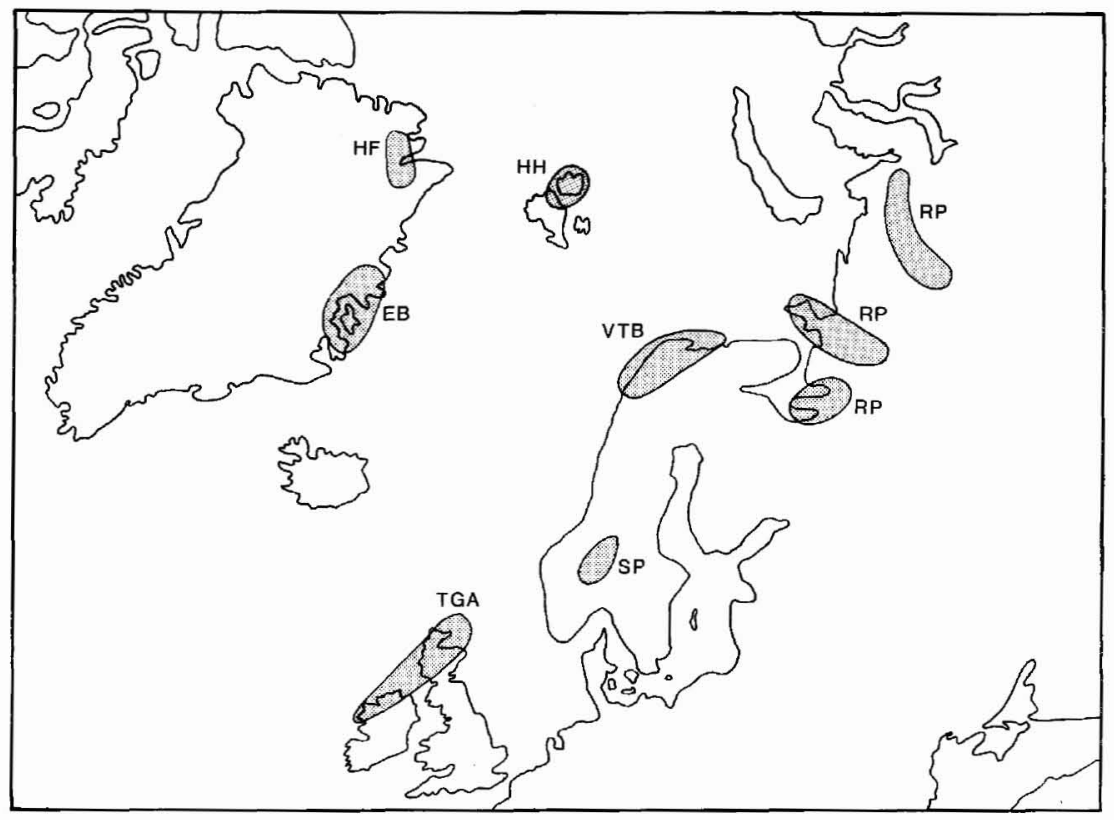

In eastern North Greenland approximately $1000 \mathrm{~m}$ of marine shallow-water deposits of Late Proterozoic age are preserved, comprising the Hagen Fjord Group (Figs 28,29 ). This succession shows a vertical evolution similar to that of the Eleonore Bay Supergroup, passing from siliciclastic shelf deposits into extensive carbonate platform deposits (Clemmensen \& Jepsen, 1992). Based on lithological similarities the group may be assumed to represent a northern equivalent of the Eleonore Bay Supergroup, having formed either in the same or in a bordering basin. There is, however, some doubt concerning the age of the Hagen Fjord Group. It may span the time from Sturtian to late Vendian (Ediacara) with a major hiatus spanning at least the Varanger Epoch, or it may be

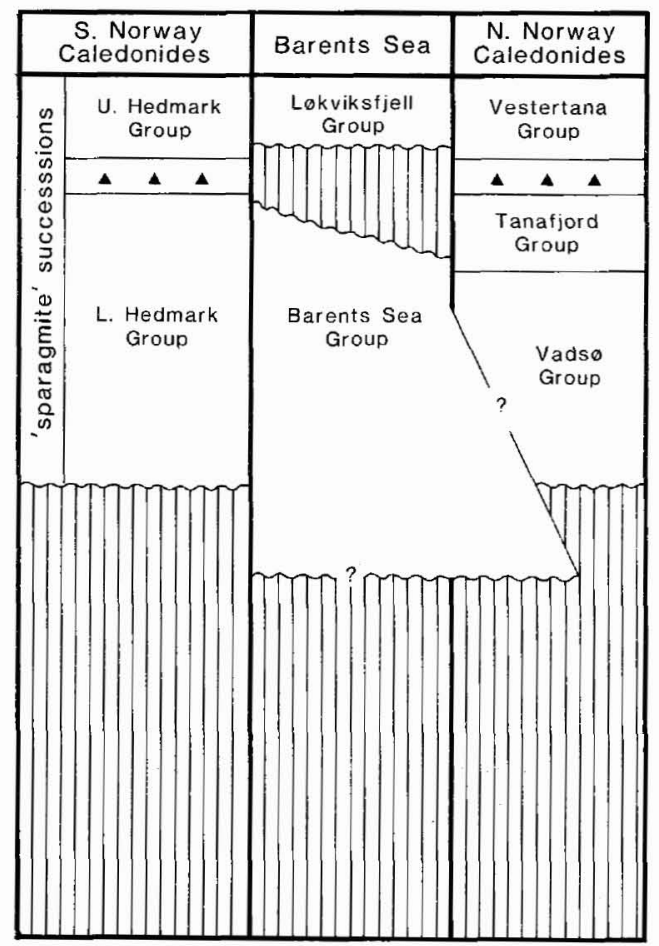

Fig. 29. Late Proterozoic correlations in the North Atlantic region. Modified from Winchester (1988) with additional data from Hambrey (1988), Rice \& Townsend (1991) and Sønderholm \& Jepsen (1991). 
entirely post-Varanger. Currently, neither possibility can be excluded and thus a firm correlation between the Hagen Fjord Group and the Eleonore Bay Supergroup cannot be made at present (Sønderholm \& Jepsen, 1991).

Late Proterozoic deposits are found in northern Scandinavia (Figs 28, 29; e.g. Føyn, 1985; Vidal, 1985; Gayer $\&$ Rice, 1989). These include the Vads $\varnothing$ and Tanafjord Groups and most of the Barents Sea Group. Based on acritarch assemblages these units can be considered coeval with the upper part of the Eleonore Bay Supergroup (Vidal, 1985). The Vads $\varnothing$ and Tanafjord Group together reach a thickness of $c$. $2500 \mathrm{~m}$, most of which consists of siliciclastic sediments. Carbonate deposits are only found within the uppermost part of the succession (Føyn, 1985). Isotopic ages from the basal mudstones of the Vads $\varnothing$ Group reveal an approximate time of deposition of 810 Ma (Føyn, 1985). The Barents Sea Group is $9000 \mathrm{~m}$ thick, of which apparently only the lower $7000 \mathrm{~m}$ is of a pre-Varanger age (Vidal, 1981). The lower part is dominated by siliciclastic deposits, with carbonate deposits developed within the upper $1000 \mathrm{~m}$ (e.g. Føyn, 1985). Glacigenic deposits are not found within the Barents Sea Group (Føyn, 1985).

It has generally been assumed that the Vads $\varnothing$ and Tanafjord Groups were formed in a basin originally widely separated from the Barents Sea Group basin, but now juxtaposed to each other by lateral movements along the Trollfjord-Komagelv fault (Johnsson et al., 1978; Føyn, 1985). The relationship between these basins and the Eleonore Bay Supergroup basin is at present uncertain as similarities in depositional environments and lithology are not obvious. Although all three successions show a characteristic increase in proportion of carbonate towards the top, this need not indicate any close relationship, as it seems to be a world-wide trend during the Late Proterozoic (e.g. Roberts, 1976). In contrast the Eleonore Bay Supergroup is considerably thicker than the northern Scandinavian successions and seems to record more continuous sedimentation (Føyn, 1985). Recently, however, Rice \& Townsend (1991) have suggested that rocks of the Barents Sea Group stratigraphically underlie the uppermost part of the Vads $\varnothing$ Group on the same side of the Trollfjord-Komagelv fault, and that stratigraphic correlation is possible across the fault. If it is found that the Barents Sea, Vads $\varnothing$ and Tanafjord Groups form a stratigraphic continuity, this may open up for new perspectives in the correlation of Late Proterozoic rocks in East Greenland and northern Scandinavia.

In southern Norway, 3000-5000 m thick Late Proterozoic successions are present in the 'sparagmite' region (Figs 28, 29) within a series of NW-SE trending riftbasins created during the initial formation of the Iapetus Ocean (Bjørlykke et al., 1976; Kumpulainen \& Nystuen,
1985; Nystuen, 1987; Nystuen \& Siedlecka, 1988; Vidal \& Nystuen, 1990). Deposition was initiated 800-750 Ma ago (Nystuen, 1987) and was accompanied by tholeiitic magmatic activity (Kumpulainen \& Nystuen, 1985). The depositional style within the 'sparagmite' basin differs considerably from that found in East Greenland. Most 'sparagmite' basins were dominated by coarse-grained continental deposits with deposition strongly influenced by tectonic activity, while shallow marine deposits only occur in the upper part. In East Greenland deposition was far more extensive and occurred on a vast and continuously subsiding shelf, and there is no evidence within the Eleonore Bay Supergroup of magmatic activity. The conspicuous differences between the 'sparagmite' successions and the Eleonore Bay Supergroup suggest that the deposits must have formed within separate basins subject to very different geological conditions.

In the British Isles, Late Proterozoic successions are extensively preserved in Scotland and Ireland (Figs 28, 29). These include the Torridon and the Sleat Groups, the Erris and Grampian Groups and the Dalradian Supergroup of which the latter three are considered to have been deposited during the opening of the lapetus Ocean (Anderton, 1985; Winchester, 1988). A possible correlation between the Torridon and Sleat Groups and the Nathorst Land Group has been suggested by Winchester (1988). The age of both the Torridon and Sleat Groups as well as the Nathorst Land Group is currently highly uncertain (e.g. Vidal, 1979; Stewart, 1988; Winchester, 1988), and there are no conspicuous similarities in lithology or depositional environments to support this contention. The Appin Group, however, is overlain by Vendian glacial deposits (Fig. 29; Hambrey, 1983; Winchester, 1988) and together with the underlying Erris and Grampian Groups must be considered coeval with part or the whole of the Eleonore Bay Supergroup but not part of the same depositional basin. Sediments are dominated by siliciclastic continental and marine deposits, with thin carbonate units present in the upper part of the Appin Group (Wright, 1988). The accumulated thickness of the two groups is in excess of $10000 \mathrm{~m}$. The depositional style within the Grampian and Appin Groups, however, is different from that of the Eleonore Bay Supergroup as sedimentation occurred within fault bounded basins and was strongly influenced by tectonic activity (Anderton, 1985; Winchester, 1988; Wright, 1988).

Late Proterozoic deposits containing Vendian (Varanger) glacial deposits and older Riphean (and Sturtian) successions are also widespread along the northern edge of the Russian Platform and along the Ural Mountain range (Fig. 28; Hambrey, 1988). These sediments include both siliciclastic and carbonate deposits. However, few sedimentary details are available and ages are generally 
poorly constrained (Vidal, 1985; Hambrey, 1988). It is generally assumed that these deposits formed in relation to the disintegration of the Late Proterozoic supercontinent (Piper, 1982), but their exact relation to the North Atlantic deposits is currently uncertain.

\section{Acknowledgements}

The participation of H. Tirsgaard was supported by grants from the Danish Research Academy (Grant No. 001-2, 5-11) and the Danish Natural Science Research Council (Grant No. 11-7444).

H.-J. Bengaard, M. J. Hambrey, N. Henriksen, A. K. Higgins and G. Vidal are thanked for critical comments on various parts of the manuscript. L. Duegaard, J. Halskov, J. Lautrup, B. Sikker Hansen and B. Thomas are thanked for technical assistance. We are grateful for help and guidance in the field to J. D. Collinson (1988) and P. R. Jakobsen (1990), and to members of the Sirius Sledge Patrol for help and hospitality on Ella $\emptyset$ and at Mesters Vig.

\section{References}

Anderton, R. 1985: Sedimentation and tectonics in the Scottish Dalradian. Scot. J. Geol. 21, 407-436.

Backlund, H. G. 1930: Contributions to the geology of Northeast Greenland. Meddr Gronland 74(11), 209-296.

Bengaard, H.-J. 1989: Geometrical and geological analysis of photogrammetrically measured deformed sediments of the fjord zone, central East Greenland. Open File Ser. Gronlands geol. Unders. 89/6, $101 \mathrm{pp}$.

Bengaard, H.-J. 1992a: Geological map 1:100 000, Alpefjord. Unpublished coloured manuscript map. Grønlands Geologiske Undersøgelse.

Bengaard, H.-J. (compiler) 1992b: Upper Proterozoic (Eleonore Bay Supergroup) to Devonian, central fjord zone, East Greenland, 1:250 000. Copenhagen: Grønlands Geologiske Undersøgelse.

Bertrand-Sarfati, J. \& Caby, R. 1976: Carbonates et stromatolites du sommet du Group d'Eleonore Bay (Précambrien terminal) au Canning Land (Groenland oriental). Bull. Grønlands geol. Unders. 119, $51 \mathrm{pp}$.

Bjørlykke, K., Elvsborg, A. \& Høy, T. 1976: Late Precambrian central sparagmite basin of south Norway. Norsk Geol. Tidsskr. 56, 233-290.

Boyd, L. A. 1935: The fiord region of East Greenland. Amer. Geogr. Soc. Spec. Publ. 18, 369 pp.

Boyd, L. A. 1948: The coast of Northeast Greenland with hydrographic studies in the Greenland Sea. Amer. Geogr. Soc. Spec. Publ. 30, 339 pp.

Bütler, H. 1948: Notes on the geological map of Canning Land (East Greenland). Meddr Grønland 133(2), 97 pp.

Caby, R. 1972: Preliminary results of mapping in the Caledonian rocks of Canning Land and Wegener Halvø, East Greenland. Rapp. Gronlands geol. Unders. 48, 21-37.

Caby, R. 1976: Investigations on the lower Eleonore Bay Group in the Alpefjord region, central East Greenland. Rapp. Grønlands geol. Unders. 80, 102-106.

Caby, R. \& Bertrand-Sarfati, J. 1988: The Eleonore Bay Group (central East Greenland). In Winchester, J. A. (ed.) Later Proterozoic stratigraphy of the northern Atlantic regions, 212-236. Glasgow: Blackie.

Cleaves, A. B. \& Fox, E. F. 1935: Geology of the west end of
Ymer Island, East Greenland. Bull. geol. Soc. Amer. 46, 463-488 and 2018-2021.

Clemmensen, L. C. \& Jepsen, H. F. 1992: Lithostratigraphy and geological setting of Upper Proterozoic shoreline-shelf deposits, Hagen Fjord Group, eastern North Greenland. Rapp. Gronlands geol. Unders. 157, 27 pp.

Eha, S. 1953: The pre-Devonian sediments on Ymers $\emptyset$, Suess Land, and Ella $\emptyset$ (East Greenland) and their tectonics. Meddr Grønland 111(2), 105 pp.

Føyn, S. 1985: The Late Precambrian in northern Scandinavia. In Gee, D. G. \& Sturt, B. A. (ed.) The Caledonide orogen Scandinavia and related areas, 233-245. London: John Wiley.

Fränkl, E. 1951: Die untere Eleonore Bay Formation im Alpefjord. Meddr Gronland 151(6), 15 pp.

Fränkl, E. 1953a: Geologische Untersuchungen in Ost-Andrées Land (NE-Grønland). Meddr Grønland 113(4), 160 pp.

Fränkl, E. 1953b: Die Geologische Karte von Nord-Scoresby Land (NE-Grønland). Meddr Grønland 113(6), 56 pp.

Friderichsen, J. D. \& Higgins, A. K. 1976: Reconnaissance work in the crystalline complexes of northern East Greenland between $72^{\circ}$ and $74^{\circ} \mathrm{N}$. Rapp. Gronlands geol. Unders. 80, 98-102.

Frykman, P. 1979: Cambro-Ordovician rocks of C. H. Ostenfeld Nunatak, northern East Greenland. Rapp. Gronlands geol. Unders. 91, 125-132.

Gayer, R. E. \& Rice, A. H. N. 1989: Palaeogeographic reconstruction of the pre- to syn-Iapetus rifting sediments in the Caledonides of Finnmark, N Norway. In Gayer, R. A. (ed.) The Caledonide geology of Scandinavia, 127-139. London: Graham \& Trotman.

Green, J. W., Knoll, A. H., Golubić, S. \& Swett, K. 1987: Paleobiology of distinctive benthic microfossils from the Upper Proterozoic Limestone-Dolomite 'Series', central East Greenland. Amer. J. Bot. 74, 928-940.

Green, J. W., Knoll, A. H. \& Swett, K. 1988: Microfossils from oolites and pisolites of the Upper Proterozoic Eleonore Bay Group, central East Greenland. J. Paleont. 62, 835-852.

Green, J. W., Knoll, A. H. \& Swett, K. 1989: Microfossils from silicified stromatolitic carbonates of the Upper Proterozoic 
Limestone-Dolomite 'Series', central East Greenland. Geol. Mag. 126, 567-585.

Haller, J. 1953: Geologie und Petrographie von West-Andrées Land und Ost-Frænkels Land (NE-Grönland). Meddr Grønland 113(5), $196 \mathrm{pp}$.

Haller, J. 1955: Der 'Zentrale Metamorphe Komplex' von NEGrönland. Teil I. Die geologische Karte von Suess Land, Gletscherland und Goodenoughs Land. Meddr Grønland 73 (1), 3, $174 \mathrm{pp}$.

Haller, J. 1958: Der 'Zentrale Metamorphe Komplex' von NEGrönland. Teil II. Die geologische Karte der Staunings Alper und des Forsblads Fjord. Meddr Gronland 154(3), 153 pp.

Haller, J. 1971: Geology of the East Greenland Caledonides, 413 pp. New York: Interscience Publishers.

Haller, J. 1983: Geological map of Northeast Greenland $75^{\circ}-82^{\circ}$ N.lat. 1:1,000,000. Meddr Grønland 200(5), 22 pp.

Hambrey, M. J. 1983: Correlation of Late Proterozoic tillites in the North Atlantic region and Europe. Geol. Mag. 120, 209 232

Hambrey, M. J. 1988: Late Proterozoic stratigraphy of the Barents Shelf. In Harland, W. B. \& Dowdeswell, E. K. (ed.) Geological evolution of the Barents Shelf region, 49-72. London: Graham \& Trotman.

Hambrey, M. J. 1989: The Late Proterozoic sedimentary record of East Greenland: its place in understanding the evolution of the Caledonide Orogen. In Gayer, R. A. (ed.) The Caledonide geology of Scandinavia, 257-262. London: Graham \& Trotman.

Hambrey, M. J. \& Spencer, A. M. 1987: Late Precambrian glaciation of central East Greenland. Meddr Gronland Ge osci. 19, $50 \mathrm{pp}$.

Hambrey, M. J., Peel, J. S. \& Smith, M. P. 1989: Upper Proterozoic and Lower Palaeozoic in northern East Greenland. Rapp. Gronlands geol. Unders. 145, 103-108.

Harland, W. B. 1975: Phanerozoic relative plate motions of North Atlantic arctic lands. In Yorath, C. J., Parker, E. R. \& Glass, D. J. (ed.) Canada's continental margins and offshore petroleum exploration. Can. Soc. Petrol. Geol. Mem. 4, 235256.

Harland, W. B. 1985: Caledonide Svalbard. In Gee, D. G. \& Sturt, B. A. (ed.) The Caledonide orogen - Scandinavia and related areas, 999-1016. London: John Wiley.

Harland, W. B. \& Gayer, R. A. 1972: The arctic Caledonides and earlier oceans. Geol. Mag. 109, 289-384.

Harland, W. B., Wallis, R. H. \& Gayer, R. A. 1966: A revision of the Lower Hecla Hoek succession in central North Spitsbergen and correlation elsewhere. Geol. Mag. 103, 70-97.

Harland, W. B., Armstrong, R. L., Cox, A. V., Craig, L. E., Smith, A. G. \& Smith, D. G. 1989: A geologic time scale, 263 pp. Cambridge: Cambridge University Press.

Harland, W. B., Scott, R. A., Auckland, K. A. \& Snape, I. 1992: The Ny Friesland Orogen, Spitzbergen. Geol. Mag. 129, 670708.

Harpøth, O., Pedersen, J. L., Schønwandt, H. K. \& Thomassen, B. 1986: The mineral occurrences of central East Greenland. Meddr Gronland Geosci. 17, 139 pp.

Henriksen, N. \& Higgins, A. K. 1976: East Greenland Caledonian fold belt. In Escher, A. \& Watt, W. S. (ed.) Geology of
Greenland, 182-246. Copenhagen: Grønlands Geologiske Undersøgelse.

Henriksen, N., Friderichsen, J. D., Strachan, R. A., Soper, N. J. \& Higgins, A. K. 1989: Caledonian and pre- Caledonian geology of the region between Grandjean Fjord and Bessel Fjord $\left(75^{\circ}-76^{\circ} \mathrm{N}\right)$, North-East Greenland. Rapp. Grønlands geol. Unders. 145, 90-97.

Herrington, P. M. \& Fairchild, I. J. 1989: Carbonate shelf and slope facies evolution prior to Vendian glaciation, central East Greenland. In Gayer, R. A. (ed.) The Caledonide geology of Scandinavia, 263-273. London: Graham \& Trotman.

Higgins, A. K. 1988: The Krummedal supracrustal sequence in East Greenland. In Winchester, J. A. (ed.) Later Proterozoic stratigraphy of the North Atlantic regions, 86-96. London: Blackie.

Higgins, A. K., Friderichsen, J. D. \& Thyrsted, T. 1977: Basement-cover relationships and metamorphic studies in the East Greenland Caledonides $\left(72^{\circ}-74^{\circ} \mathrm{N}\right)$. Rapp. Gronlands geol. Unders. 85, 109-114.

Higgins, A. K., Friderichsen, J. D. \& Thyrsted, T. 1981: Precambrian metamorphic complexes in the East Greenland Caledonides $\left(72^{\circ}-74^{\circ} \mathrm{N}\right)$ - their relationships to the Eleonore Bay Group, and Caledonian orogenesis. Rapp. Gronlands geol. Unders. 104, 5-46.

Hochstetter, F. v. 1874: Geologische Karten-Skizze von OstGrönland. In Koldewey, K. (ed.) Die zweite Deutsche Nordpolfahrt in den Jahren 1869 und 1870 unter Führung des Kapitän Karl Koldewey 2(3). Leipzig: E. A. Brockhaus.

Huber, W. 1950: Geologisch-Petrographische Untersuchungen in der innern Fjordregions des Kejser Frans Josephs Fjordsystems in Nordostgrönland. Meddr Gronland 151(3), 83 pp.

IUGS, 1989: Global stratigraphic chart. Supplement to Episodes 12(2).

Jensen, S. M. 1993: Lead isotope studies on mineral showings and ore deposits in East Greenland. Rapp. Gronlands geol. Unders. 159, 101-108.

Johnson, H. G., Levell, B. H. \& Siedlecki, S. 1978: Late Precambrian sedimentary rocks in East Finnmark, north Norway and their relationship to the Trollfjord-Komagelv fault. $J$. geol. Soc. Lond. 135, 517-533.

Katz, H. R. 1952: Zur Geologie von Strindbergs Land (NEGrönland). Meddr Grønland 111(1), 115 pp.

Katz, H. R. 1961: Late Precambrian to Cambrian stratigraphy in East Greenland. In Raasch, G. O. (ed.) Geology of the Arctic 1, 299-328. Toronto: Toronto University Press.

Knoll, A. H., Golubić, S., Green, J. W. \& Swett, K. 1986a: Organically preserved microbial endoliths from the late Proterozoic of East Greenland. Nature 321 (6073), 856-857.

Knoll, A. H., Hayes, J. M., Kaufman, A. J., Swett, K. \& Lambert, I. B. 1986b: Secular variation in carbon isotope ratios from Upper Proterozoic successions of Svalbard and East Greenland. Nature 321 (6073), 832-838.

Koch, L. 1929a: The geology of East Greenland. Meddr Gronland 73(2), 1, 1-204.

Koch, L: 1929b: Stratigraphy of Greenland. Meddr Grønland 73(2), 2, 205-320.

Koch, L. \& Haller, J. 1971: Geological map of East Greenland $72^{\circ}-76^{\circ}$ N.Lat. (1:250,000). Meddr Grønland 183, 26 pp. 
Kulling, O. 1930: Stratigraphic studies of the geology of northeast Greenland. Meddr Grønland 74(13), 317-346.

Kumpulainen, R. \& Nystuen, J. P. 1985: Late Proterozoic basin evolution and sedimentation in the westernmost part of Baltoscandia. In Gee, D. G. \& Sturt, B. A. (ed.) The Caledonide orogen - Scandinavia and related areas, 213-233. London: John Wiley.

Larsen, P.-H. \& Bengaard, H.-J. 1991: Devonian basin initiation in East Greenland: a result of sinistral wrench faulting and Caledonian extensional collapse. J. geol. Soc. Lond. 148, $335-368$.

Lenz, O. 1874: Spezielle Darstellung der geologischen Verhältnisse Ostgrönlands. In Koldewey, K. (ed.) Die zweite Deutsche Nordpolfahrt in den Jahren 1869 und 1870 unter Führung des Kapitän Karl Koldewey 2(3), 481-496. Leipzig: E. A. Brockhaus.

Moncrieff, A. C. M. 1989: The Tillite Group and related rocks of East Greenland: implications for Late Proterozoic palaeogeography. In Gayer, R. A. (ed.) The Caledonide geology of Scandinavia, 285-297. London: Graham \& Trotman.

Nathorst, A. G. 1901: Bidrag til nordöstra Grönlands geologi. Geol. Fören. Stockholm Förh. 23, 275-306.

Nordenskiöld, A. E. 1863: Geografisk och geognostisk beskrifning öfver nordöstra delarne af Spetsbergen och Hinlopen Strait. K. Svenska VetenskAkad. Handl. 4(7), 25 pp.

Nordenskjöld, O. 1907: On the geology and physical geography of East-Greenland. Meddr Grønland 28(5), 151-284.

Nystuen, J. P. 1987: Synthesis of the tectonic and sedimentological evolution of the late Proterozoic - early Cambrian Hedmark Basin, the Caledonian thrust belt, southern Norway. Norsk Geol. Tidsskr. 67, 395-418.

Nystuen, J. P. \& Siedlecka, A. 1988: The 'Sparagmites' of Norway. In Winchester, J. A. (ed.) Later Proterozoic stratigraphy of the northern Atlantic regions, 237-252. Glasgow: Blackie.

Odell, N. E. 1939: The structure of the Kejser Franz Josephs Fjord region, North-East Greenland. Meddr Grønland 119(6), $53 \mathrm{pp}$.

Odell, N. E. 1944: The petrography of the Franz Josef Fjord region, North-East Greenland, in relation to its structures. Trans. R. Soc. Edinb. 61(1), 221-246.

Olsen, H. \& Larsen, P.-H. 1993: Lithostratigraphy of the continental Devonian sediments in North-East Greenland. Bull. Gronlands geol. Unders. 165, 108 pp.

Parkinson, M. M. L. \& Whittard, W. F. 1931: The geological work of the Cambridge Expedition to East Greenland in 1929. Q. J. geol. Soc. Lond. 87, 650-674.

Peucat, J. J., Tisserant, D., Caby, R. \& Clauer, N. 1985: Resistance of zircons to resetting in a prograde metamorphic sequence of Caledonian age, East Greenland. Can. J. Earth Sci. 22, 330-338.

Piper, J. D. A. 1982: The Precambrian paleomagnetic record: the case for the Proterozoic Supercontinent. Earth Planet. Sci. Lett. 59, 61-89.

Poulsen, C. 1930: Contributions to the stratigraphy of the Cambro-Ordovician of East Greenland. Meddr Gronland 74, 297 316.

Poulsen, C. \& Wienberg-Rasmussen, H. 1951: Geological map (scale 1:50,000) and description of Ella $\emptyset$. Meddr Grønland 151(5), 25 pp. (also Bull. Grønlands geol. Unders. 3).

Read, J. F. 1982: Carbonate platforms of passive (extensional) continental margins: types, characteristics and evolution. Tectonophysics 81, 195-212.

Rex, D. C. \& Gledhill, A. R. 1981: Isotopic studies in the East Greenland Caledonides $\left(72^{\circ}-74^{\circ} \mathrm{N}\right)$ - Precambrian and Caledonian ages. Rapp. Gronlands geol. Unders. 104, 47-72.

Rice, A. H. N. \& Townsend, C. 1991: Comments on the geology of the North Varanger region, Finnmark, N Norway. Terra Nova 3, Abstr. Supp. 4, 26 only.

Roberts, J. D. 1976: Late Precambrian dolomites, Vendian glaciation, and synchroneity of Vendian glaciations. J. Geol. 84, $47-63$.

Schaub, H. P. 1950: On the Pre-Cambrian to Cambrian sedimentation in NE-Greenland. Meddr Gronland 114(10), 50 pp.

Schidlowski, M., Eichmann, R. \& Junge, C. E. 1975: Precambrian sedimentary carbonates: carbon and isotope geochemistry and implications for the terrestrial oxygen budget. Precambrian Res. 2, 1-71.

Sommer, M. 1957a: Geologie von Lyells Land (NE-Grönland). Meddr Grønland 155(2), 157 pp.

Sommer, M. 1957b: Geologische Untersuchungen in den Praekambrischen Sedimenten zwischen Grandjeans Fjord und Bessels Fjord $\left(75^{\circ}-76^{\circ}\right.$ n. Br.) in NE-Grönland. Meddr Grønland $160(2), 56 \mathrm{pp}$.

Sønderholm, M. \& Jepsen, H. F. 1991: Proterozoic basins of North Greenland. In Peel, J. S. \& Sønderholm, M. (ed.) Sedimentary basins of North Greenland. Bull. Gronlands geol. Unders. 160, 49-69.

Sønderholm, M. \& Tirsgaard, H. 1990: Sedimentological investigation of the Multicoloured 'series' (Eleonore Bay Group, Late Precambrian) in the Scoresby Land - Andree Land region, North-East Greenland. Rapp. Gronlands geol. Unders. 148, 115-122.

Sønderholm, M. \& Tirsgaard, H. (unpublished): Stratigraphy and sedimentology of the Lyell Land and Ymer $\varnothing$ Groups (Eleonore Bay Supergroup, Late Proterozoic) of East Greenland.

Sønderholm, M., Collinson, J. D. \& Tirsgaard, H. 1989: Stratigraphic and sedimentological studies of the Eleonore Bay Group (Precambrian) between $73^{\circ} 30^{\prime} \mathrm{N}$ and $76^{\circ} \mathrm{N}$ in East Greenland. Rapp. Gronlands geol. Unders. 145, 97-102.

Soper, N. J. \& Higgins, A. K. 1993: Basement-cover relationships in the East Greenland Caledonides: evidence from the Eleonore Bay Supergroup at Ardencaple Fjord. Trans. R. Soc. Edinb. 84.

Steiger, R. H., Hansen, B. T., Schuler, C., Bär, M. T. \& Henriksen, N. 1979: Polyorogenic nature of the southern Caledonian fold belt in East Greenland: an isotopic age study. J. Geology 87, 475-495.

Stewart, A. D. 1988: The Sleat and Torridon Groups. In Winchester, J. A. (ed.) Later Proterozoic stratigraphy of the northern Atlantic regions, 104-112. London: Blackie.

Surlyk, F. 1978: Mesozoic geology and palaeogeography of Hochstetter Forland, East Greenland. Bull. geol. Soc. Denm. 27, 73-87.

Swett, K. \& Knoll, A. H. 1989: Marine pisolites from Upper 
Proterozoic carbonates of East Greenland and Spitsbergen. Sedimentology 36, 75-93.

Teichert, C. 1933: Untersuchungen zum Bau des Kaledonischen Gebirges in Ostgönland. Meddr Grónland 95(1), 121 pp.

Tirsgaard, H. in press: The architecture of Precambrian high energy tidal channels: an example from the Lyell Land Group (Eleonore Bay Supergroup), East Greenland. Sedim. Geol.

Toula, F. 1874: Allgemeine Uebersicht der geologischen Beschaffenheit Ostgrönlands. In Koldewey, K. (ed.) Die zweite Deutsche Nordpolfahrt in den Jahren 1869 und 1870 unter Führung des Kapitän Karl Koldewey 2(3), 475-480. Leipzig: E. A. Brockhaus.

Vidal, G. 1976: Late Precambrian acritarchs from the Eleonore Bay Group and Tillite Group in East Greenland. Rapp. Grønlands geol. Unders. 78, 19 pp.

Vidal, G. 1979: Acritarchs from the Upper Proterozoic and Lower Cambrian of East Greenland. Bull. Gronlands geol. Unders. 134, 40 pp.

Vidal, G. 1981: Micropalaeontology and biostratigraphy of the Upper Proterozoic and Lower Cambrian sequence in East Finnmark, northern Norway. Norges geol. Unders. 362, 53 pp.

Vidal, G. 1985: Biostratigraphic correlation of the Upper Proterozoic and Lower Cambrian of the Fennoscandian Shield and the Caledonides of East Greenland and Svalbard. In Gee, D. G. \& Sturt, B. A. (ed.) The Caledonide orogen - Scandinavia and related areas, 331-338. London: John Wiley.
Vidal, G. \& Nystuen, J. P. 1990: Micropaleontology, depositional environment, and biostratigraphy of the Upper Proterozoic Hedmark Group, southern Norway. In Knoll, A. H. \& Ostrom, J. H. (ed.) Proterozoic evolution and environments. Amer. J. Sci. 290A, 170-211.

Wegmann, C. E. 1935: Preliminary report on the Caledonian orogeny in Christian X's Land (North-East Greenland). Meddr Gronland 103(3), 59 pp.

Wenk, E. \& Haller, J. 1953: Geological explorations in the Petermann region, western part of Frænkels Land, East Greenland. Meddr Grønland 111(3), 48 pp.

Winchester, J. A. 1988: Later Proterozoic environments and tectonic evolution in the northern Atlantic lands. In Winchester, J. A. (ed.) Later Proterozoic stratigraphy of the northern Atlantic regions, 253-270. London: Blackie.

Wordie, J. M. 1927: The Cambridge expedition to East Greenland 1926. V. Geology. Geogr. J. 70, 252-253.

Wordie, J. M. 1930: Cambridge East Greenland Expedition, 1929: ascent of Petermann Peak. Geogr. J. 75, 481-504.

Wordie, J. M. \& Whittard, W. F. 1930: A contribution to the geology of the country between Petermann Peak and Kjerulf Fjord, East Greenland. Geol. Mag. 67, 145-158.

Wright, A. E. 1988: The Appin Group. In Winchester, J. A. (ed.) Later Proterozoic stratigraphy of the northern Atlantic regions, 177-199. London: Blackie.

Zweifel, H. 1959: Geologie und Petrographie von Nathorsts Land (NE-Grönland). Meddr Grønland 160(3), 94 pp. 